Article

\title{
Innovative Approach of Non-Thermal Plasma Application for Improving the Growth Rate in Chickens
}

\author{
Jiao Jiao Zhang ${ }^{1}{ }^{(\mathbb{D})}$, Xian Zhong Wang ${ }^{2}$, Taeho Kwon ${ }^{3}{ }^{(\mathbb{D})}$, Do Luong Huynh ${ }^{1}{ }^{(1)}$, \\ Nisansala Chandimali ${ }^{1}$, Nameun Kim ${ }^{1}$ (D), Tae Yoon Kang ${ }^{1}$, Mrinmoy Ghosh ${ }^{1}$, Meeta Gera ${ }^{1}$, \\ Sang Baek Lee ${ }^{4}$, Sung Jin Lee ${ }^{5}$, Wang Shik Lee ${ }^{6}$, Seong Bong Kim ${ }^{7}$, Young Sun Mok ${ }^{4, *}$ (i) \\ and Dong Kee Jeong 1,3,*
}

1 Laboratory of Animal Genetic Engineering and Stem Cell Biology, Department of Advanced Convergence Technology and Science, Jeju National University, Jeju 63243, Korea; zhangjjff@126.com (J.J.Z.); denishhuynh@gmail.com (D.L.H.); nimminisha28@gmail.com (N.C.); nameun82@gmail.com (N.K.); tyfy3@nate.com (T.Y.K.); mringhs2010@gmail.com (M.G.); mee21988@gmail.com (M.G.)

2 Chongqing Key Laboratory of Forage and Herbivore, College of Animal Science and Technology, Southwest University, Chongqing 400715, China; xianzhong_wang@aliyun.com

3 Laboratory of Animal Genetic Engineering and Stem Cell Biology, Subtropical/Tropical Organism Gene Bank, Jeju National University, Jeju 63243, Korea; taehokwonk@gmail.com

4 Department of Chemical and Biological Engineering, Jeju National University, Jeju 63243, Korea; sblee@jejunu.ac.kr

5 Department of Animal Biotechnology, College of Animal Bioscience and Technology, Kangwon National University, Chunchon 24341, Korea; Sjlee@kangwon.ac.kr

6 Department of Animal Biotechnology, College of Applied Life Sciences, Jeju National University, Jeju 63243, Korea; leewshik@naver.com

7 Plasma Technology Research Center, National Fusion Research Institute, Gunsan-si, Jeollabuk-Do 54004, Korea; sbkim@nfri.re.kr

* Correspondence: smokie@jejunu.ac.kr (Y.S.M.); newdkjeong@gmail.com (D.K.J.); Tel.: +82-10-4530-4482 (Y.S.M.); +82-64-754-3331 (D.K.J.)

Received: 15 June 2018; Accepted: 3 August 2018; Published: 6 August 2018

\begin{abstract}
As an innovative technology in biological applications-non-thermal plasma technique-has recently been applied to living cells and tissues. However, it is unclear whether non-thermal plasma treatment can directly regulate the growth and development of livestock. In this study, we exposed four-day-incubated fertilized eggs to plasma at $11.7 \mathrm{kV}$ for $2 \mathrm{~min}$, which was found to be the optimal condition in respect of highest growth rate in chickens. Interestingly, plasma-treated male chickens conspicuously grew faster than females. Plasma treatment regulated the reactive oxygen species homeostasis by controlling the mitochondrial respiratory complex activity and up-regulating the antioxidant defense system. At the same time, growth metabolism was improved due to the increase of growth hormone and insulin-like growth factor 1 and their receptors expression, and the rise of thyroid hormones and adenosine triphosphate levels through the regulation of demethylation levels of growth and hormone biosynthesis-related genes in the skeletal muscles and thyroid glands. To our knowledge, this study was the first to evaluate the effects of a non-thermal plasma treatment on the growth rate of chickens. This safe strategy might be beneficial to the livestock industry.
\end{abstract}

Keywords: non-thermal plasma; growth metabolism; demethylation; ATP; GH-IGF1; thyroid hormones 


\section{Introduction}

Non-thermal plasma systems have the potential for a wide-range of biological applications in living cells and tissues [1] because of no substantial gas heating. Our laboratory has established a non-thermal dielectric barrier discharge (DBD) plasma system generated in argon at atmospheric pressure for creating electrically safe plasma [2-6]. A previous study suggested that an appropriate non-thermal DBD plasma treatment improved the seed germination and sprout growth in soybeans [5]. However, it is unclear whether non-thermal plasma treatment can directly regulate the growth and development of livestock. In this study, the non-thermal DBD plasma technique was implemented in fertilized eggs before hatching for the evaluation of the optimal plasma treatment conditions. In vitro experiments using fibroblasts [7], endothelial cells [8], epithelial cells [1], and myoblast cells [9] demonstrate a plasma dose-dependent effect. These previous studies suggested that plasma intensity and exposure time could result in differentiation of growth-promoting effects in chickens.

Numerous small pores in the palisades of chicken eggshell permit the potential diffusion of active charged and neutral particles in plasma, which generates reactive oxygen species (ROS) when exposed on the surface of cells or tissues [10]. Diffusion of plasma-produced ROS or accumulation of plasma-stimulated intracellular ROS [11,12] regulate cell proliferation and differentiation $[8,13]$ and mitochondrial biogenesis [14]. Non-thermal plasma-produced appropriate extracellular ROS increases skeletal cell differentiation and limb development of mouse through the activation and amplification of intracellular ROS-sensitive signaling pathways [15]. However, excessive accumulation of intracellular ROS induces cell apoptosis $[6,16,17]$. In this study, we try to investigate whether plasma-produced ROS or stimulation of intracellular ROS mediate the chicken growth.

A genome-wide DNA methylation map in chickens displayed analogous hallmarks of classic vertebrate patterns [18]. DNA methylation is negatively correlated with gene transcription in birds [18]. DNA hypomethylation generally correlates with the activation of gene expression and acceleration of metabolic activity [19]. However, hypermethylation suppresses gene expression by disturbing the binding of specific transcription factors [20]. DNA methylation levels of differentially methylated cytosine guanine (CG) sites are correlated with the relative maternal stress levels during pregnancy [21]. Thus, we hypothesize that the non-thermal DBD plasma treatment on fertilized chicken eggs may change the DNA methylation levels during the developmental process. Furthermore, sex differences at the DNA methylation level have previously been studied in skeletal muscles [22]. Chromosome-wide and gene-specific sex differences in DNA methylation are associated with differential gene expression and metabolism [23]. Females tend to have greater DNA methylation levels on both the allosomes and autosomes than males [24]. As a result, we predict that plasma may induce changes in methylation levels that differ between female and male chickens.

The aim of the present study was therefore to determine whether non-thermal DBD plasma treatment can affect the chicken growth. We also investigate whether the plasma effect differs by sex and how plasma regulates energy metabolism during the developmental process.

\section{Results}

\subsection{Optimization of Plasma Treatment Condition on the Chicken Growth}

Chickens in the group exposed to $22.0 \mathrm{kV}$ for $1 \mathrm{~min}$ showed the highest average daily gain (ADG) and longest average tibia length among all plasma-treated groups in the first month (Table 1). The ADG and tibia length of chickens exposed to $11.7 \mathrm{kV}$ for 2 min exhibited the maximum values among all plasma-treated groups at the age of 90 days, with increases of 0.15 - and 0.11 -fold $(p<0.001)$ in females and 0.23 - and 0.12 -fold $(p<0.001)$ in males, respectively, when compared with the females and males of the control group (Table 1). The photographs of 90-day-old chickens in the plasma group exposed to $11.7 \mathrm{kV}$ for $2 \mathrm{~min}$ and the control group were shown in Figure 1. Interestingly, plasma-treated male chickens showed conspicuously faster growth rate than females (Table 1). Higher potential plasma 
$(27.6 \mathrm{kV})$ produced inhibitory effects on chicken growth parameters (Table 1). Thus, non-thermal DBD plasma exposure at $11.7 \mathrm{kV}$ for $2 \mathrm{~min}$ was used as the optimal condition for further experiments.

Table 1. Effect of plasma exposure at different potential and duration on the average daily gain (ADG) and tibia length of chickens.

\begin{tabular}{|c|c|c|c|c|c|c|c|}
\hline Gender & Group & $\begin{array}{c}\text { ADG } \\
\text { (Day 0-30) } \\
\text { (g/d) }\end{array}$ & $\begin{array}{l}\text { Average Tibia } \\
\text { Length on } \\
\text { Day } 30(\mathrm{~cm})\end{array}$ & $\begin{array}{c}\text { ADG } \\
(\text { Day } 0-60)(g / d)\end{array}$ & $\begin{array}{l}\text { Average Tibia } \\
\text { Length on } \\
\text { Day } 60(\mathrm{~cm})\end{array}$ & $\begin{array}{c}\text { ADG } \\
\text { (Day 0-90) } \\
\text { (g/d) }\end{array}$ & $\begin{array}{c}\text { Average Tibia } \\
\text { Length on } \\
\text { Day } 90(\mathrm{~cm})\end{array}$ \\
\hline \multirow{13}{*}{ Female } & Control & $7.66 \pm 0.13^{\mathrm{cd}}$ & $5.37 \pm 0.05^{\mathrm{d}}$ & $7.68 \pm 0.06^{d}$ & $8.27 \pm 0.05^{\mathrm{fg}}$ & $8.81 \pm 0.04$ ef & $11.58 \pm 0.13^{\mathrm{de}}$ \\
\hline & $11.7 \mathrm{kV}-30 \mathrm{~s}$ & $7.91 \pm 0.10^{b c}$ & $5.60 \pm 0.08^{c}$ & $7.95 \pm 0.14^{\mathrm{cd}}$ & $8.43 \pm 0.12$ ef & $8.93 \pm 0.14^{\text {def }}$ & $11.81 \pm 0.17^{\mathrm{cd}}$ \\
\hline & $11.7 \mathrm{kV}-1 \mathrm{~min}$ & $7.94 \pm 0.07 \mathrm{bc}$ & $5.70 \pm 0.08^{c}$ & $10.04 \pm 0.15^{\mathrm{a}}$ & $9.13 \pm 0.09^{b}$ & $9.66 \pm 0.10^{b}$ & $11.99 \pm 0.03^{b c}$ \\
\hline & $11.7 \mathrm{kV}-2 \mathrm{~min}$ & $8.42 \pm 0.28^{b}$ & $6.13 \pm 0.05^{b}$ & $10.28 \pm 0.31^{\mathrm{a}}$ & $9.60 \pm 0.08^{a}$ & $10.10 \pm 0.09^{a}$ & $12.88 \pm 0.04^{a}$ \\
\hline & $16.4 \mathrm{kV}-30 \mathrm{~s}$ & $7.98 \pm 0.08^{b c}$ & $5.67 \pm 0.12^{c}$ & $8.03 \pm 0.13^{\mathrm{cd}}$ & $8.63 \pm 0.09$ de & $9.04 \pm 0.11$ cde & $11.89 \pm 0.10^{c}$ \\
\hline & $16.4 \mathrm{kV}-1 \mathrm{~min}$ & $8.07 \pm 0.38^{b c}$ & $6.17 \pm 0.05^{b}$ & $8.23 \pm 0.18^{c}$ & $8.90 \pm 0.08^{c}$ & $9.13 \pm 0.20^{\mathrm{cd}}$ & $12.01 \pm 0.08^{b c}$ \\
\hline & $16.4 \mathrm{kV}-2 \mathrm{~min}$ & $7.65 \pm 0.17^{\mathrm{cd}}$ & $5.60 \pm 0.08^{c}$ & $8.02 \pm 0.28^{\mathrm{cd}}$ & $8.57 \pm 0.05^{\mathrm{de}}$ & $9.05 \pm 0.08$ cde & $11.76 \pm 0.20^{\mathrm{cd}}$ \\
\hline & $22.0 \mathrm{kV}-30 \mathrm{~s}$ & $8.58 \pm 0.60^{b}$ & $6.33 \pm 0.17^{b}$ & $8.28 \pm 0.02^{c}$ & $8.73 \pm 0.05^{\mathrm{cd}}$ & $9.13 \pm 0.14^{\mathrm{cd}}$ & $11.89 \pm 0.05^{c}$ \\
\hline & $22.0 \mathrm{kV}-1 \mathrm{~min}$ & $9.67 \pm 0.49^{a}$ & $6.67 \pm 0.12^{\mathrm{a}}$ & $8.91 \pm 0.22^{b}$ & $8.93 \pm 0.12 b c$ & $9.24 \pm 0.05^{c}$ & $12.20 \pm 0.04^{b}$ \\
\hline & $22.0 \mathrm{kV}-2 \mathrm{~min}$ & $7.60 \pm 0.13^{\mathrm{cd}}$ & $5.63 \pm 0.05^{c}$ & $8.11 \pm 0.30^{\mathrm{cd}}$ & $8.20 \pm 0.14^{g}$ & $8.75 \pm 0.14^{f}$ & $11.48 \pm 0.20^{\mathrm{e}}$ \\
\hline & $27.6 \mathrm{kV}-30 \mathrm{~s}$ & $8.22 \pm 0.37 b c$ & $5.70 \pm 0.08^{c}$ & $8.16 \pm 0.10^{c}$ & $8.10 \pm 0.08$ gh & $8.43 \pm 0.06 \mathrm{~g}$ & $11.34 \pm 0.03^{\text {ef }}$ \\
\hline & $27.6 \mathrm{kV}-1 \mathrm{~min}$ & $7.03 \pm 0.18^{\text {de }}$ & $5.10 \pm 0.16^{\mathrm{e}}$ & $8.09 \pm 0.23^{\mathrm{cd}}$ & $7.97 \pm 0.17^{\mathrm{hi}}$ & $8.36 \pm 0.09 \mathrm{~g}$ & $11.17 \pm 0.06^{\mathrm{fg}}$ \\
\hline & $27.6 \mathrm{kV}-2 \mathrm{~min}$ & $6.79 \pm 0.22 e^{\mathrm{e}}$ & $5.03 \pm 0.09^{\mathrm{e}}$ & $7.92 \pm 0.23^{\mathrm{cd}}$ & $7.77 \pm 0.05^{\mathrm{i}}$ & $8.25 \pm 0.20 \mathrm{~g}$ & $11.08 \pm 0.11 \mathrm{~g}$ \\
\hline \multirow{13}{*}{ Male } & Control & $7.74 \pm 0.16^{\mathrm{d}}$ & $5.90 \pm 0.08^{\mathrm{d}}$ & $8.91 \pm 0.12^{f}$ & $9.23 \pm 0.12^{\mathrm{e}}$ & $9.51 \pm 0.19$ ef & $12.93 \pm 0.08^{f}$ \\
\hline & $11.7 \mathrm{kV}-30 \mathrm{~s}$ & $8.72 \pm 0.37^{c}$ & $6.27 \pm 0.12^{c}$ & $10.06 \pm 0.12^{\text {cde }}$ & $9.37 \pm 0.12 \mathrm{de}$ & $10.37 \pm 0.05^{b c}$ & $13.11 \pm 0.03^{\text {ef }}$ \\
\hline & $11.7 \mathrm{kV}-1 \mathrm{~min}$ & $8.80 \pm 0.35^{c}$ & $6.40 \pm 0.08^{c}$ & $10.24 \pm 0.16^{\mathrm{cd}}$ & $9.57 \pm 0.12^{\mathrm{cd}}$ & $10.47 \pm 0.13^{b}$ & $13.41 \pm 0.11^{\mathrm{cd}}$ \\
\hline & $11.7 \mathrm{kV}-2 \mathrm{~min}$ & $10.39 \pm 0.30^{b}$ & $6.83 \pm 0.05^{b}$ & $12.17 \pm 0.09^{\mathrm{a}}$ & $10.57 \pm 0.17^{\mathrm{a}}$ & $11.65 \pm 0.09^{a}$ & $14.52 \pm 0.03^{a}$ \\
\hline & $16.4 \mathrm{kV}-30 \mathrm{~s}$ & $8.98 \pm 0.29^{c}$ & $6.40 \pm 0.08^{c}$ & $10.07 \pm 0.15^{\text {cde }}$ & $9.57 \pm 0.12^{\mathrm{cd}}$ & $9.89 \pm 0.05^{\mathrm{de}}$ & $13.39 \pm 0.17^{\mathrm{cd}}$ \\
\hline & $16.4 \mathrm{kV}-1 \mathrm{~min}$ & $8.97 \pm 0.48^{c}$ & $6.80 \pm 0.08^{b}$ & $10.37 \pm 0.23^{c}$ & $9.57 \pm 0.09^{\mathrm{cd}}$ & $9.93 \pm 0.40^{\mathrm{d}}$ & $13.50 \pm 0.15^{c}$ \\
\hline & $16.4 \mathrm{kV}-2 \mathrm{~min}$ & $8.33 \pm 0.18^{c}$ & $6.20 \pm 0.14^{c}$ & $10.18 \pm 0.32^{\mathrm{cd}}$ & $9.30 \pm 0.08^{\mathrm{e}}$ & $9.43 \pm 0.14^{\mathrm{f}}$ & $13.19 \pm 0.13^{\mathrm{de}}$ \\
\hline & $22.0 \mathrm{kV}-30 \mathrm{~s}$ & $9.93 \pm 0.21^{b}$ & $6.73 \pm 0.17^{b}$ & $10.47 \pm 0.27^{b c}$ & $9.43 \pm 0.05^{\mathrm{de}}$ & $9.51 \pm 0.24$ ef & $13.44 \pm 0.10^{\mathrm{cd}}$ \\
\hline & $22.0 \mathrm{kV}-1 \mathrm{~min}$ & $11.32 \pm 0.14^{\mathrm{a}}$ & $7.03 \pm 0.09^{a}$ & $10.83 \pm 0.05^{b}$ & $9.70 \pm 0.22^{b}$ & $10.06 \pm 0.08^{\mathrm{cd}}$ & $13.85 \pm 0.07^{b}$ \\
\hline & $22.0 \mathrm{kV}-2 \mathrm{~min}$ & $7.19 \pm 0.18^{\text {def }}$ & $5.87 \pm 0.05^{\mathrm{d}}$ & $9.68 \pm 0.13^{e}$ & $8.63 \pm 0.05^{f}$ & $8.74 \pm 0.13 \mathrm{~g}$ & $12.04 \pm 0.20 \mathrm{~g}$ \\
\hline & $27.6 \mathrm{kV}-30 \mathrm{~s}$ & $7.46 \pm 0.31 \mathrm{de}$ & $5.30 \pm 0.08^{\mathrm{e}}$ & $9.82 \pm 0.22$ de & $7.90 \pm 0.08^{g}$ & $8.23 \pm 0.09^{h}$ & $11.06 \pm 0.11^{h}$ \\
\hline & $27.6 \mathrm{kV}-1 \mathrm{~min}$ & $6.85 \pm 0.29$ ef & $5.13 \pm 0.05^{\mathrm{e}}$ & $8.82 \pm 0.30^{f}$ & $7.83 \pm 0.05 \mathrm{~g}$ & $8.10 \pm 0.26^{h}$ & $10.97 \pm 0.07^{\mathrm{h}}$ \\
\hline & $27.6 \mathrm{kV}-2 \mathrm{~min}$ & $6.68 \pm 0.27^{f}$ & $5.10 \pm 0.08^{\mathrm{e}}$ & $6.04 \pm 0.19 \mathrm{~g}$ & $7.73 \pm 0.05 \mathrm{~g}$ & $7.25 \pm 0.16^{\mathrm{i}}$ & $10.22 \pm 0.11^{\mathrm{i}}$ \\
\hline
\end{tabular}

Data are presented as mean \pm standard deviation (SD) $(n=20)$ of three replicates; $n$ represents an individual chicken. Within a column: different lowercase letters indicate significant differences $(p<0.05)$ in females and males, respectively, according to the one-way ANOVA with a least significant difference (LSD) test.

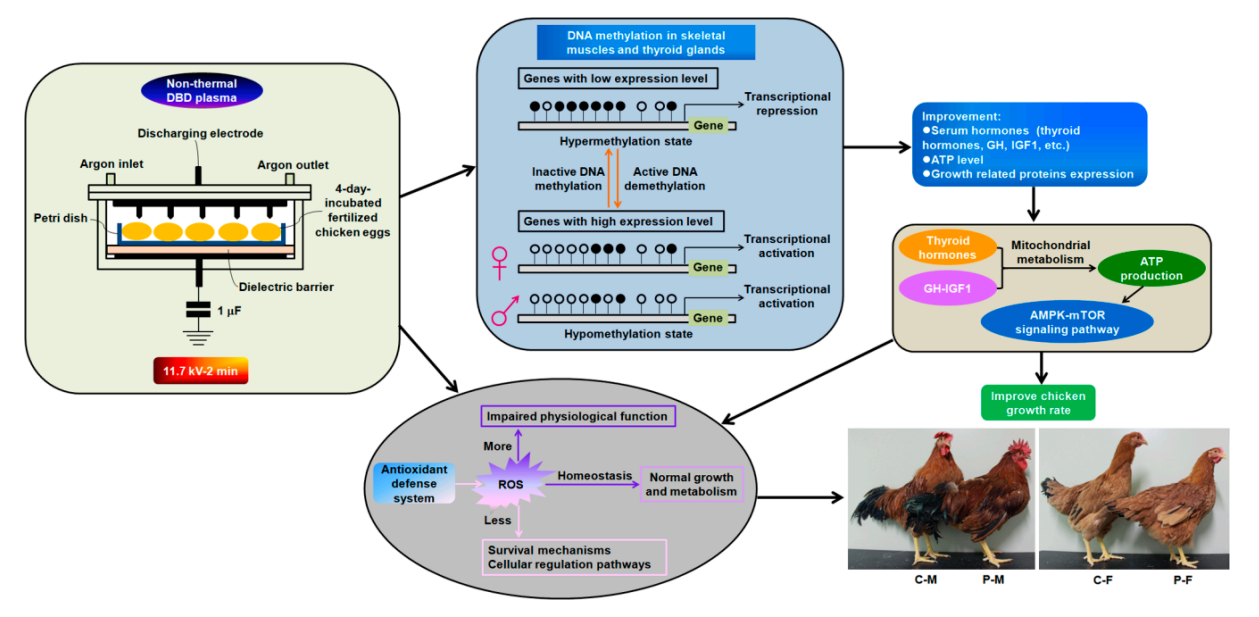

Figure 1. Description of the mechanism of how non-thermal dielectric barrier discharge (DBD) plasma affect chicken growth. The optimal plasma treatment condition is $11.7 \mathrm{kV}$ for $2 \mathrm{~min}$. Representative chicken growth status on day 90 is shown. C-M represents male chickens in the control group; $\mathrm{P}-\mathrm{M}$ represents male chickens in the plasma treatment group. C-F represents female chickens in the control group; P-F represents female chickens in the plasma treatment group. The antioxidant defense system-mediated reactive oxygen species (ROS) homeostasis regulates the growth performance. DNA methylation in skeletal muscles and thyroid glands is involved in the regulation of chicken growth rate. $\bullet$ represent methylated cytosine, and $\bigcirc$ represent unmethylated cytosine. 


\subsection{Chicken Serum Hormone Levels}

Compared to 30-day-old females and males in the control group, plasma exposure at $11.7 \mathrm{kV}$ for 2 min significantly increased the serum concentrations of triiodothyronine (T3) in both females and males (Figure 2a), free thyroxine (FT4) in females (Figure 2d), and insulin-like growth factor 1 (IGF1) in both females and males (Figure 2f), but decreased insulin-like growth factor binding protein 2 (IGFBP2) in males (Figure 2g). Compared to 60-day-old females and males in the control group, plasma exposure significantly increased the serum concentrations of T3, thyroxine (T4), and IGF1 in males (Figure 2a,b,f), but decreased IGFBP2 in both females and males (Figure 2g). Compared to 90-day-old females and males in the control group, plasma exposure significantly increased the serum concentrations of $\mathrm{T} 3$ and T4 in both females and males (Figure 2a,b), free triiodothyronine (FT3) and FT4 in males (Figure 2c,d), and growth hormone (GH) and IGF1 in both females and males (Figure 2e,f), but decreased IGFBP2 in both females and males (Figure 2g). Specifically, male chickens showed greater changes in those serum hormone levels than female chickens after plasma treatment. The detailed parameters on day 90 showed that plasma treatment increased 0.32- $(p=0.001)$ and 0.91 -fold $(p<0.001)$ of T3 in females and males (Figure 2a), 0.06- ( $p=0.011)$ and 0.10-fold $(p=0.033)$ of T4 in females and males (Figure 2b), $0.16-(p=0.071)$ and 0.21 -fold $(p=0.028)$ of FT3 in females and males (Figure $2 c), 0.15-(p=0.235)$ and 0.31 -fold $(p=0.002)$ of FT4 in females and males (Figure $2 \mathrm{~d}), 0.29-(p=0.023)$ and 0.78 -fold $(p=0.002)$ of GH in females and males (Figure 2e), and 0.24- $(p=0.011)$ and 0.83 -fold $(p<0.001)$ of IGF1 in females and males (Figure 2f), respectively, compared to 90-day-old females and males in the control group. However, the serum IGFBP2 level showed a $0.17-(p=0.016)$ and 0.43 -fold $(p=0.001)$ decrease in 90-day-old females and males after plasma exposure (Figure 2g).

(a)

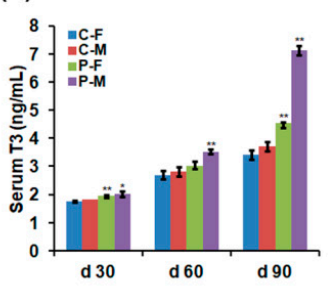

(e)

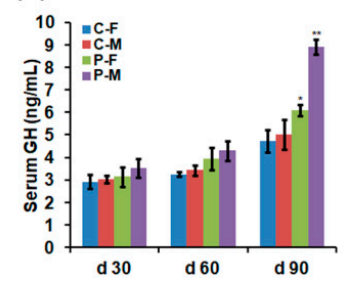

(b)

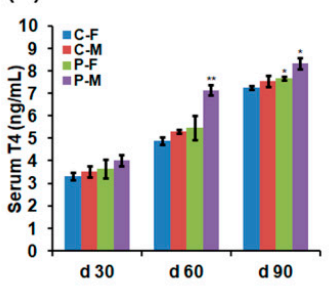

(f)

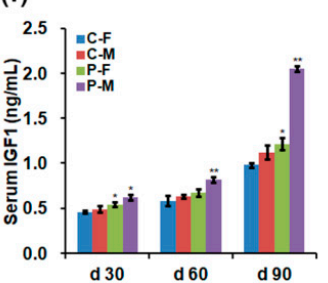

(c)

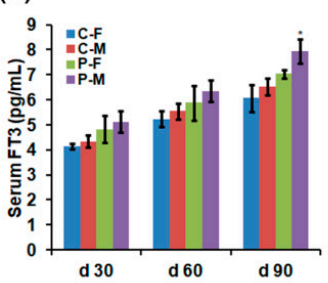

(g)

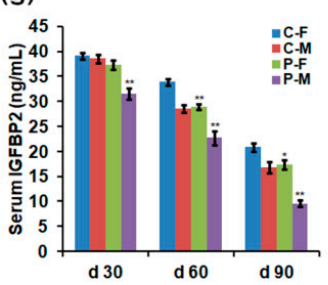

(d)

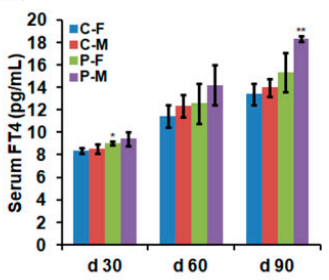

Figure 2. Chicken serum hormone levels on days 30, 60, and 90. (a) triiodothyronine (T3), (b) thyroxine (T4), (c) free triiodothyronine (FT3), (d) free thyroxine (FT4), (e) growth hormone (GH), (f) insulin-like growth factor 1 (IGF1), and (g) insulin-like growth factor binding protein 2 (IGFBP2). Data are presented as mean $\pm \mathrm{SD}(n=10)$ of three replicates; $\mathrm{n}$ represents an individual chicken. ${ }^{*}, p<0.05$ versus control; $* *, p<0.01$ versus control in females and males, respectively, on days 30,60 , and 90 , according to the one-way ANOVA with an LSD test.

\subsection{Adenosine Triphosphate (ATP), ROS, and Antioxidant Enzyme Levels}

Optimal plasma exposure significantly increased the concentrations of ATP, superoxide dismutase (SOD), catalase (CAT), and glutathione peroxidase (GPx) but reduced ROS and malondialdehyde (MDA) levels in chicken sera on days 30, 60, and 90 (Figure 3) and in different organs on day 90 (Figure 4). The detailed parameters revealed that males showed that values of ATP, ROS, and antioxidant enzymes varied in a greater extent than females after plasma treatment (Figures 3 and 4). In terms of ATP level on day 90, plasma-treated females and males showed increases 
of 0.55- $(p=0.003)$ and 1.06-fold $(p<0.001)$ in the serum (Figure 3a), 0.19- $(p=0.101)$ and 0.83-fold $(p=0.001)$ in the heart, 0.48- $(p=0.027)$ and 0.96-fold $(p=0.002)$ in the liver, $0.32-(p=0.172)$ and 0.77 -fold $(p=0.004)$ in the gizzard, 0.34- $(p=0.027)$ and 0.75 -fold $(p=0.004)$ in the intestine, and 0.43$(p=0.009)$ and 0.92 -fold $(p<0.001)$ in the skeletal muscle (Figure $4 \mathrm{a})$, respectively, compared to 90-day-old females and males in the control group. However, ROS level of females and males on day 90 were negatively affected by plasma treatment, showing decreases of $0.13-(p=0.001)$ and 0.34 -fold $(p<0.001)$ in the serum (Figure 3b), 0.12- $(p<0.001)$ and 0.14-fold $(p<0.001)$ in the heart, 0.09 $(p<0.001)$ and 0.10 -fold $(p<0.001)$ in the liver, $0.15-(p=0.004)$ and 0.17 -fold $(p=0.001)$ in the gizzard, 0.14- $(p<0.001)$ and 0.19 -fold $(p<0.001)$ in the intestine, and 0.19- $(p<0.001)$ and 0.31 -fold $(p<0.001)$ in the skeletal muscle (Figure $4 \mathrm{~b}$ ), respectively, compared to those in the controls. Moreover, MDA level of females and males on day 90 were also negatively affected by plasma treatment, showing decreases of $0.24-(p=0.031)$ and 0.52 -fold $(p=0.001)$ in the serum (Figure $3 c), 0.32-(p=0.021)$ and 0.56 -fold $(p<0.001)$ in the heart, $0.23-(p=0.065)$ and 0.37 -fold $(p=0.010)$ in the liver, $0.20-(p=0.143)$ and 0.38 -fold $(p=0.001)$ in the gizzard, 0.11- $(p=0.420)$ and 0.31-fold $(p=0.006)$ in the intestine, and 0.34- $(p=0.015)$ and 0.53 -fold $(p<0.001)$ in the skeletal muscle (Figure $4 \mathrm{c})$, respectively. In terms of SOD activity on day 90, plasma-treated females and males showed increases of $0.19-(p=0.100)$ and 0.27 -fold $(p=0.013)$ in the serum (Figure $3 \mathrm{~d}), 0.18-(p=0.002)$ and 0.20 -fold $(p=0.002)$ in the heart, $0.26-(p=0.012)$ and 0.34 -fold $(p=0.003)$ in the liver, $0.11-(p=0.052)$ and 0.21 -fold $(p=0.024)$ in the gizzard, 0.11- $(p=0.077)$ and 0.22-fold $(p=0.028)$ in the intestine, and 0.20- $(p=0.035)$ and 0.31-fold $(p=0.004)$ in the skeletal muscle (Figure $4 \mathrm{~d})$, respectively, compared to those in the controls. In terms of CAT activity on day 90, plasma-treated females and males showed increases of $0.38-(p=0.021)$ and 0.74-fold $(p=0.002)$ in the serum (Figure 3e), 0.38- $(p=0.015)$ and 0.73-fold $(p=0.005)$ in the heart, 0.33 $(p=0.018)$ and 0.97 -fold $(p=0.004)$ in the liver, $0.17-(p=0.132)$ and 0.68 -fold $(p=0.004)$ in the gizzard, 0.17 - $(p=0.158)$ and 0.68 -fold $(p=0.019)$ in the intestine, and $0.32-(p=0.073)$ and 0.83 -fold $(p<0.001)$ in the skeletal muscle (Figure 4e), respectively, compared to those in the controls. In addition, GPx activity of females and males on day 90 were increased by plasma treatment, with increases of 0.18$(p=0.006)$ and 0.25 -fold $(p=0.07)$ in the serum (Figure $3 f), 0.21-(p=0.008)$ and 0.36 -fold $(p=0.009)$ in the heart, 0.17- $(p=0.013)$ and 0.32 -fold $(p<0.001)$ in the liver, $0.36-(p<0.001)$ and 0.57 -fold $(p<0.001)$ in the gizzard, 0.61- $(p<0.001)$ and 0.81-fold $(p<0.001)$ in the intestine, and 0.11- $(p=0.024)$ and 0.55 -fold $(p<0.001)$ in the skeletal muscle (Figure $4 \mathrm{f})$, respectively, compared to those in the controls.

(a)

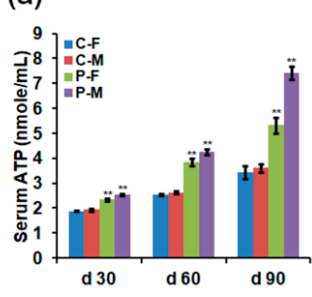

(d)

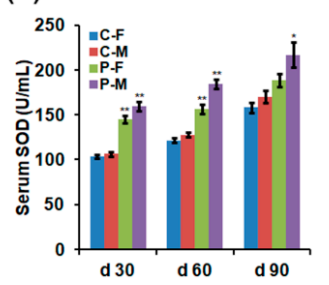

(b)

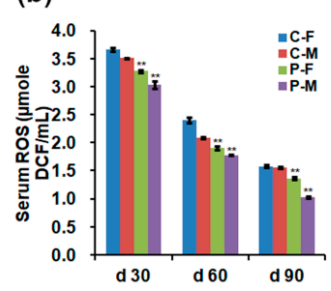

(e)

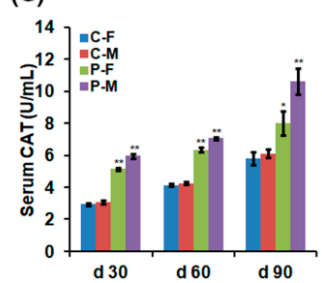

(c)

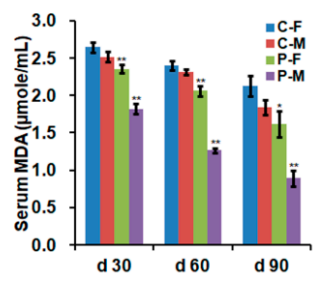

(f)

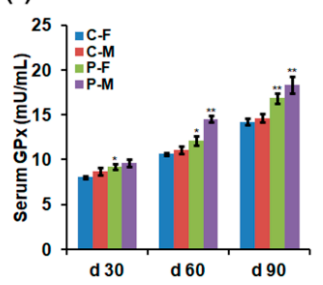

Figure 3. Concentrations of (a) adenosine triphosphate (ATP), (b) ROS, (c) malondialdehyde (MDA), (d) superoxide dismutase (SOD), (e) catalase (CAT), and (f) glutathione peroxidase (GPx) in the serum of chickens on days 30,60, and 90. Data are presented as mean $\pm \mathrm{SD}(n=10)$ of three replicates; $\mathrm{n}$ represents an individual chicken. ${ }^{*}, p<0.05$ versus control; ${ }^{* *}, p<0.01$ versus control in females and males, respectively, on days 30, 60, and 90, according to the one-way ANOVA with an LSD test. 
(a)

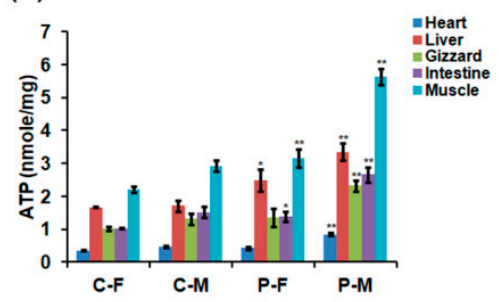

(d)

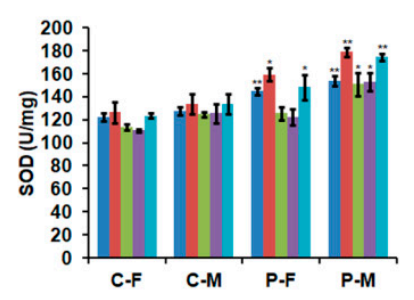

(b)

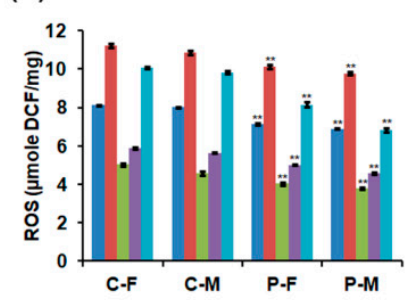

(e)

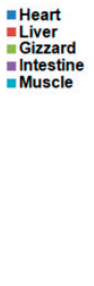

\section{8}

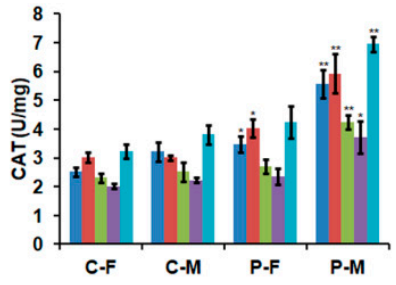

(c)
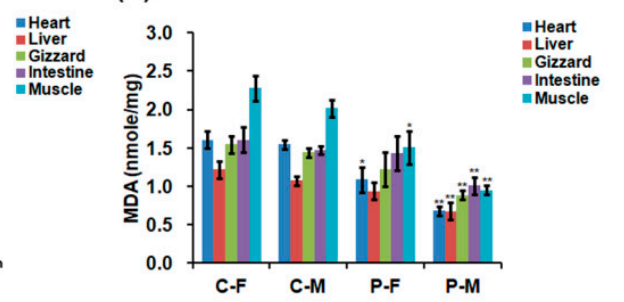

(f)

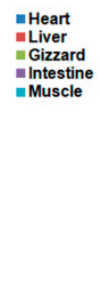

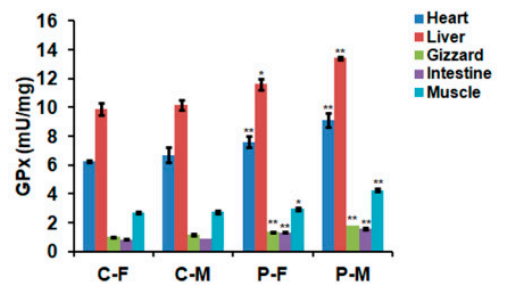

Figure 4. Concentrations of (a) ATP, (b) ROS, (c) MDA, (d) SOD, (e) CAT, and (f) GPx in different organs of 90 -day-old chickens. Data are presented as mean \pm SD $(n=10)$ of three replicates; $\mathrm{n}$ represents an individual chicken. ${ }^{*}, p<0.05$ versus control; $* *, p<0.01$ versus control in females and males, respectively, according to the one-way ANOVA with an LSD test.

\subsection{Ultrastructure of Skeletal Muscles and Mitochondrial Respiratory Enzyme Levels in Male Chickens}

Considering greater growth parameters presented in the plasma-treated male chickens, we investigated the ultrastructure of skeletal muscles and mitochondrial respiratory complex activity in skeletal muscles of males. The results showed that the number of mitochondria present between the myofibrils in the longitudinal section of the skeletal muscles of plasma-treated male chickens aged 90 days was greater than in the control group (Figure 5a). The optimal plasma exposure increased the levels of nicotinamide adenine dinucleotide hydrogen (NADH) (Figure 5b), cytochrome c oxidase (Figure 5c), and ATP synthase (Figure $5 \mathrm{~d}$ ) by $0.44-(p=0.001), 0.30-(p=0.003)$, and 0.41 -fold $(p=0.004)$ in the skeletal muscle mitochondria of 90-day-old male chickens.

\subsection{Expressions of $m R N A$ and Protein in the Skeletal Muscles}

The optimal plasma exposure significantly increased the mRNA expression of ATP5 synthase, $G H$, growth hormone receptor (GHR), IGF1, insulin-like growth factor 1 receptor (IGF1R), POU class 1 homeobox 1 (POU1F1), mammalian target of rapamycin (mTOR), and peroxiredoxins (PRDXs) but decreased the mRNA expression of IGFBP2 and adenosine monophosphate-activated protein kinase $(A M P K)$ in the skeletal muscle of chickens on day 90 (Figure 6a-d). In addition, plasma treatment increased the mRNA expression of thyroglobulin (TG), thyroid peroxidase (TPO), and thyroid hormone receptors (THRs) in the thyroid glands of chickens on day 90 (Figure 6e). Plasma treatment activated mTOR phosphorylation and increased the protein expression of ATP5A, GHR, and PRDX3 in the skeletal muscles, with increases of 1.99- $(p=0.018)$ and 5.43-fold $(p<0.001)$ in mTOR phosphorylation (Figure 7a,c); 0.90- $(p=0.003)$ and 1.29-fold ( $p=0.001)$ in ATP5A (Figure 7a,d); 3.34- $(p<0.001)$ and 2.03-fold $(p=0.001)$ in GHR (Figure 7a,d); and 3.42- $(p=0.002)$ and 3.62-fold $(p=0.001)$ in PRDX3 (Figure $7 \mathrm{a}, \mathrm{d}$ ) in the skeletal muscle of female and male chickens compared to those in the controls. However, plasma treatment decreased AMPK $\alpha$ phosphorylation by $0.81-(p<0.001)$ and 0.94 -fold $(p<0.001)$ and IGFBP 2 protein expression by $0.23-(p=0.042)$ and 0.30 -fold $(p=0.012)$ in the skeletal muscle of female and male chickens (Figure 7a,b,d). Uncropped immunoblots in the skeletal muscle of chickens are presented in Figure S1. Interestingly, males exhibited greater changes in mRNA levels of the examined enzymes than females after plasma treatment. 
(a)

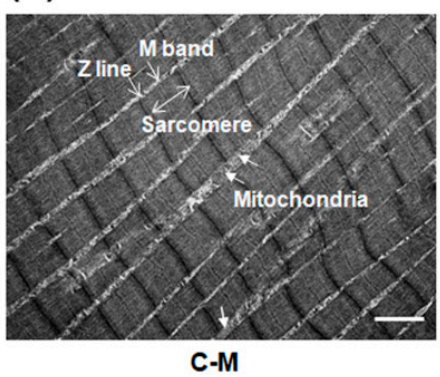

C-M

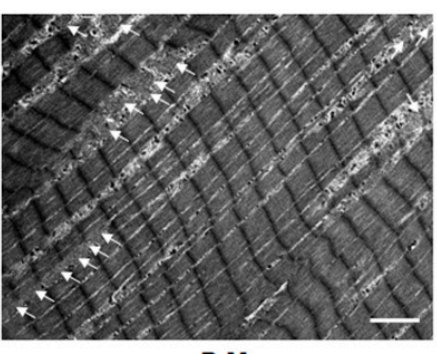

P-M (b)

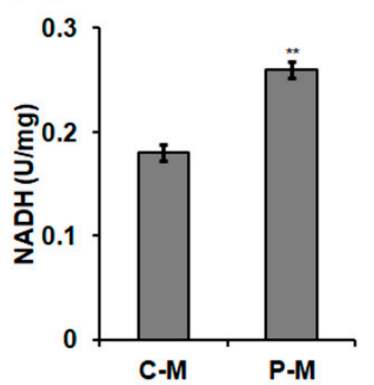

(c)

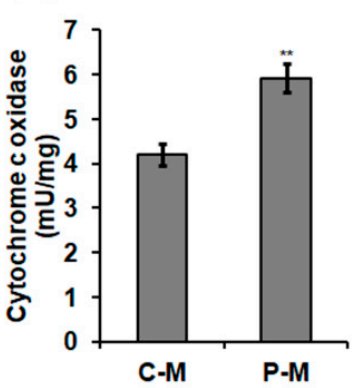

(d)

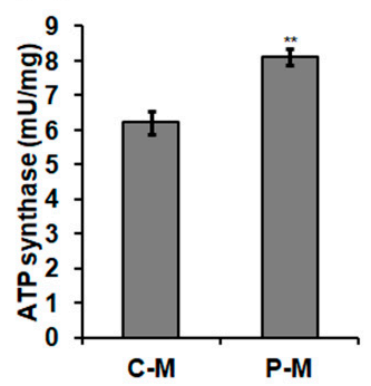

Figure 5. Ultrastructure of skeletal muscles and mitochondrial respiratory enzyme levels in 90-day-old male chickens. (a) Representative longitudinal section of skeletal muscles. Z line, M band, and sarcomere in the myofibril are clearly observed. Mitochondria located between myofibrils are photographed using a transmission electron microscopy. The arrow shows the mitochondrion. Scale bar: $2.0 \mu \mathrm{m}$. (b) Nicotinamide adenine dinucleotide hydrogen (NADH) levels in the mitochondria of skeletal muscles. Activities of mitochondrial respiratory enzyme (c) cytochrome c oxidase and (d) ATPase synthase in skeletal muscles. Data are presented as mean $\pm \mathrm{SD}(n=10)$ of three replicates; $\mathrm{n}$ represents an individual chicken. ${ }^{* *}, p<0.01$ versus control, according to the one-way ANOVA with an LSD test.

(a)

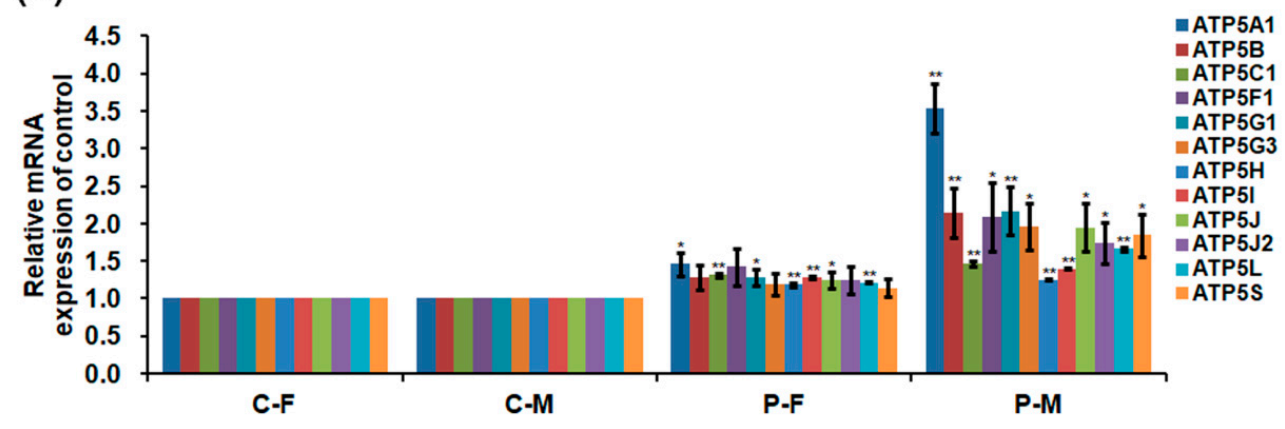

(b)

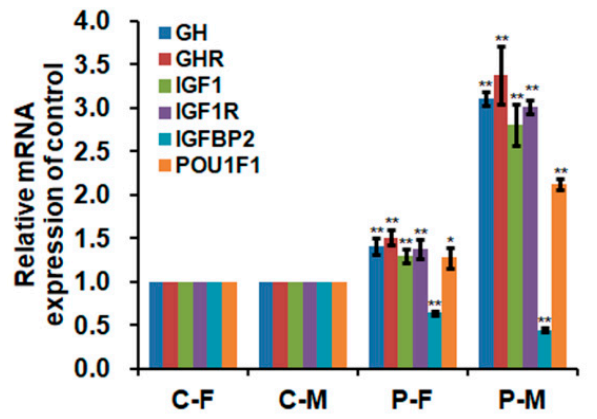

(c)

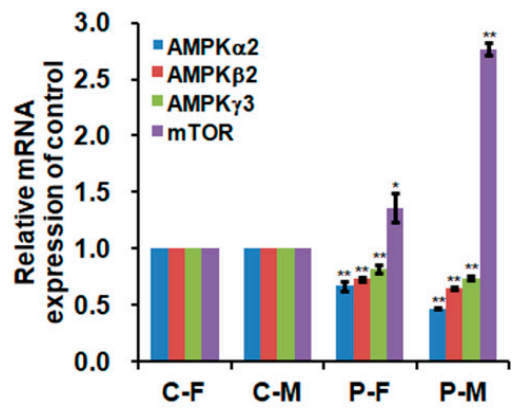

Figure 6. Cont. 
(d)

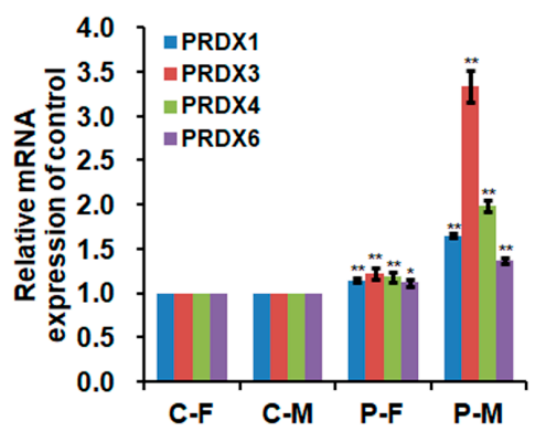

(e)

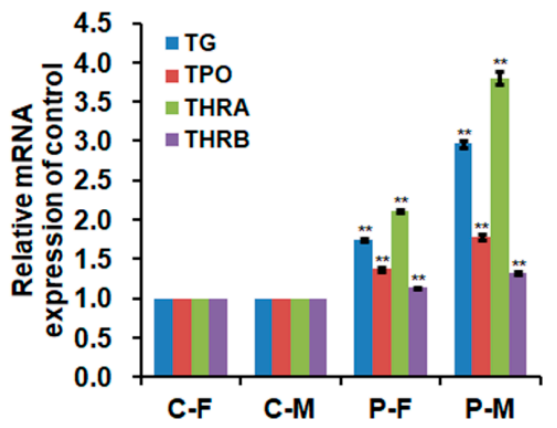

Figure 6. Relative mRNA levels of (a) ATP5 synthase; (b) $G H$, growth hormone receptor (GHR), IGF1, insulin-like growth factor 1 receptor (IGF1R), IGFBP2, and POU class 1 homeobox 1 (POU1F1); (c) adenosine monophosphate-activated protein kinase $(A M P K) \alpha 2, A M P K \beta 2, A M P K \gamma 3$, and mammalian target of rapamycin (mTOR), and (d) peroxiredoxin (PRDX) 1, PRDX3, PRDX4, and PRDX6 in the skeletal muscles of 90-day-old chickens; Relative mRNA levels of thyroglobulin (TG), thyroid peroxidase (TPO), thyroid hormone receptor alpha (THRA), and thyroid hormone receptor beta (THRB) (e) in the thyroid glands of 90-day-old chickens. Data are presented as mean $\pm \mathrm{SD}(n=10)$ of three replicates; $\mathrm{n}$ represents an individual chicken. ${ }^{*}, p<0.05$ versus control; ${ }^{* *}, p<0.01$ versus control in females and males, respectively, according to the one-way ANOVA with an LSD test.

(a)

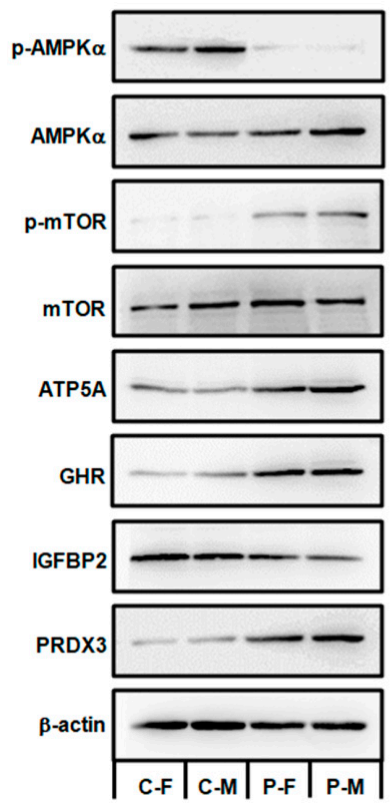

(b)

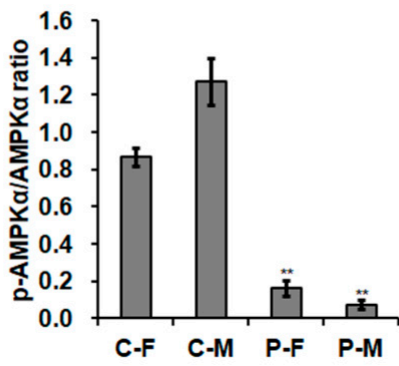

(d)

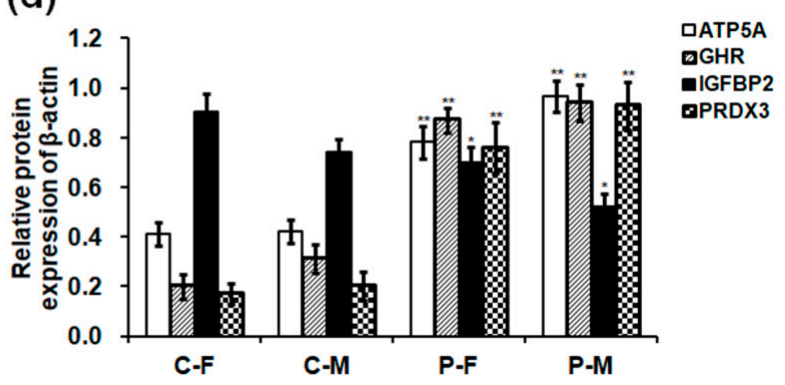

Figure 7. Effect of plasma on protein expression in 90-day-old chickens. (a) Western blot analysis of protein bands in the skeletal muscles. Uncropped immunoblot scans are presented in Figure S1. Relative protein levels of (b) p-AMPK $\alpha /$ AMPK $\alpha$, (c) p-mTOR/mTOR, and (d) ATP5A, GHR, IGFBP2, and PRDX3. Data are presented as mean $\pm \mathrm{SD}(n=3)$ of three replicates; $n$ represents an individual chicken. ${ }^{*}, p<0.05$ versus control; ${ }^{* *}, p<0.01$ versus control in females and males, respectively, according to the one-way ANOVA with an LSD test.

\subsection{DNA Methylation Level}

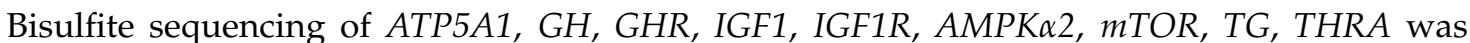
performed to determine the exact location, type, and extent of methylation. The sequence analysis results of these genes using CyMATE software are reported in Figure 8. Methylation levels in the 
sequenced regions of genes in the plasma-treated group decreased in the skeletal muscle of females and males on day 90 by, in corresponding order, 0.06- and 0.16-fold in ATP5A1, 0.10- and 0.15-fold in GH, 0.07- and 0.14-fold in GHR, 0.07- and 0.11-fold in IGF1, 0.03- and 0.14-fold in IGF1R, and 0.06- and 0.15 -fold in $m T O R$. Methylation levels decreased by 0.17 - and 0.21 -fold in TG and 0.06- and 0.10-fold in THRA in the thyroid gland of females and males compared to those in the controls (Table 2). However, plasma treatment increased methylation levels in the sequenced region of $A M P K \alpha 2$ by 0.18 - and 0.21-fold in the skeletal muscle of females and males (Table 2). The decrease in average methylation levels for CG, CHG (where H correspond to adenosine, thymine, or cytosine), and CHH sites in the sequenced regions of ATP5A1, GH, GHR, IGF1, IGF1R, $m T O R, T G$, and THRA and the increase in average methylation levels for each type of $A M P K \alpha 2$ in males were greater than those in females after plasma treatment (Figure 9).
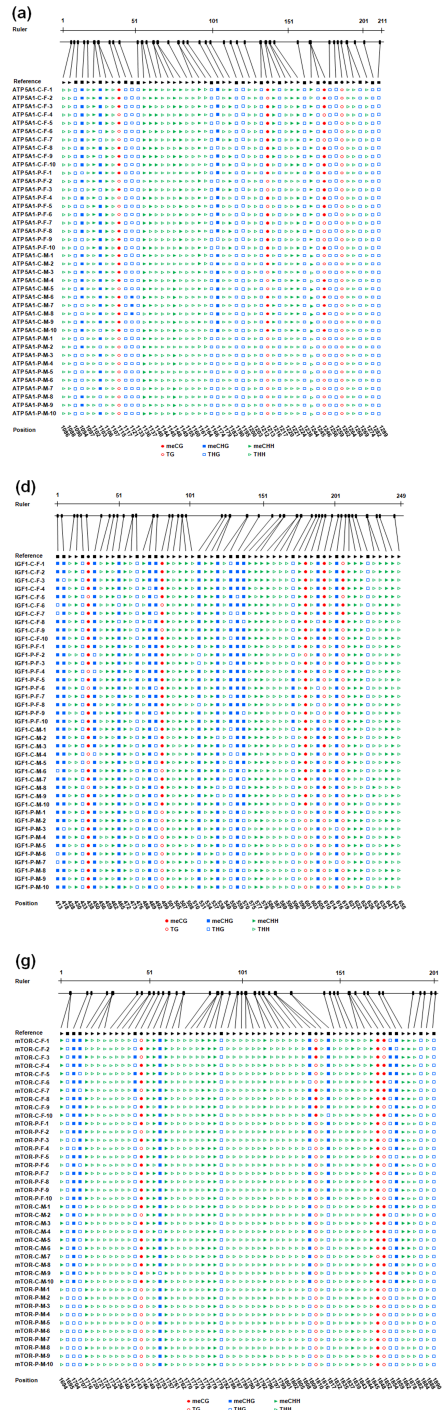
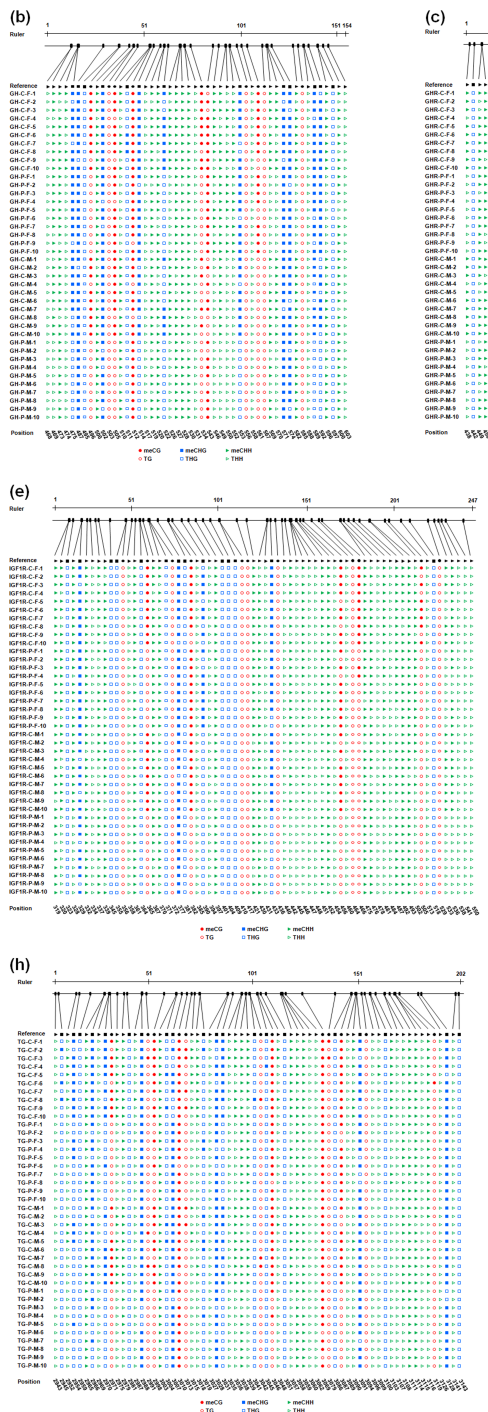
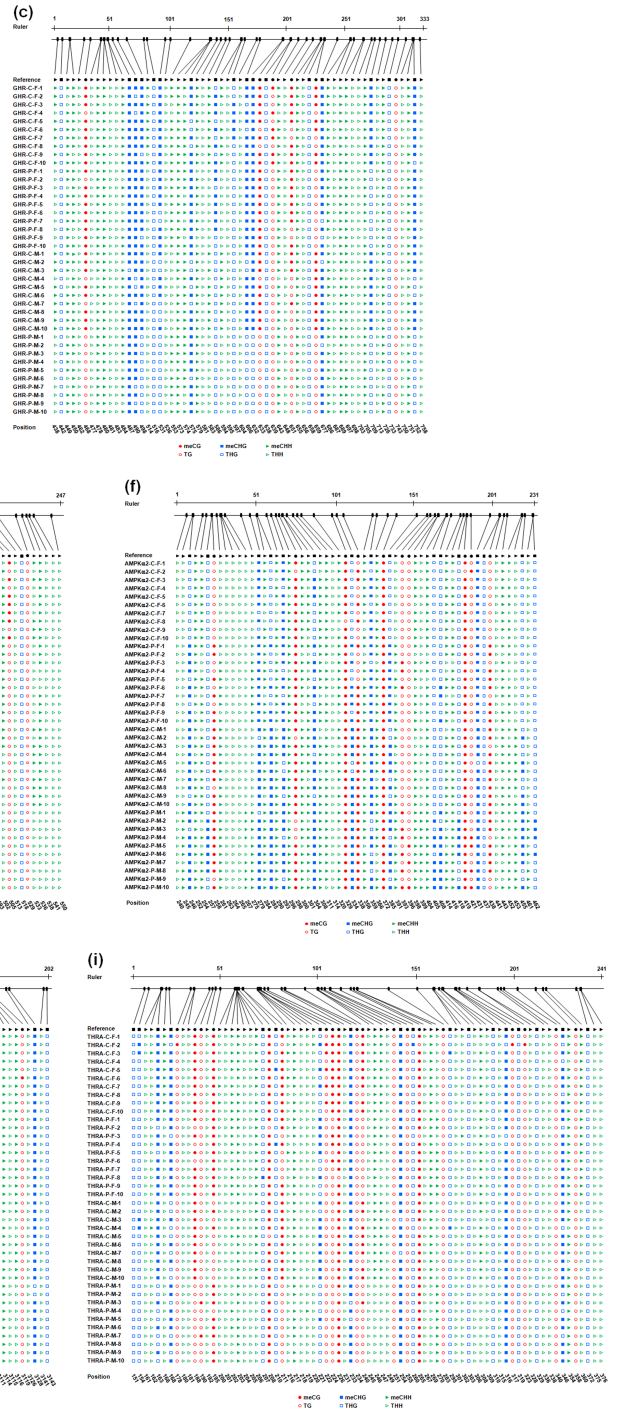

Figure 8. Cytosine methylation analysis in 90-day-old chickens. Bisulfite sequencing results of (a) ATP5A1, (b) GH, (c) GHR, (d) IGF1, (e) IGF1R, (f) AMPK $\alpha 2$, and (g) mTOR in the skeletal muscles, (h) TG, and (i) THRA in the thyroid glands. The length of sequenced region and exact location of cytosine are shown schematically. The order of individual sequences of ten clones is listed on the left. Reference sequence is shown in the first line. The sequence is distinguished by circles for cytosine guanine (CG), squares for CHG (where H correspond to adenosine, thymine, or cytosine), and triangles for $\mathrm{CHH}$. Filled symbols represent methylated cytosine, and open symbols represent unmethylated cytosine. 
Table 2. DNA methylation levels (\%).

\begin{tabular}{|c|c|c|c|c|c|}
\hline Tissues & Genes & C-F & C-M & P-F & P-M \\
\hline \multirow{7}{*}{ Skeletal muscles } & ATP5A1 & 29.81 & 22.50 & 23.85 & 6.35 \\
\hline & GH & 62.24 & 46.94 & 52.24 & 32.04 \\
\hline & GHR & 54.33 & 44.17 & 47.33 & 30.67 \\
\hline & $I G F 1$ & 61.79 & 53.57 & 54.64 & 42.50 \\
\hline & $I G F 1 R$ & 42.35 & 40.00 & 39.12 & 25.88 \\
\hline & $A M P K \alpha 2$ & 40.00 & 52.41 & 57.93 & 73.10 \\
\hline & mTOR & 35.41 & 27.38 & 29.84 & 12.13 \\
\hline \multirow{2}{*}{ Thyroid glands } & TG & 47.42 & 41.82 & 30.61 & 20.61 \\
\hline & THRA & 33.68 & 26.05 & 28.03 & 16.45 \\
\hline
\end{tabular}

Genes in the skeletal muscles and thyroid glands of female and male chickens on day 90 are bisulfite sequenced. The cytosine methylation analysis results see Figure 8. C-F represents female chickens in the control group; C-M represents male chickens in the control group; P-F represents female chickens in the plasma treatment group; P-M represents male chickens in the plasma treatment group. ATP5A1, ATP synthase, $\mathrm{H}^{+}$transporting, mitochondrial F1 complex, alpha subunit 1; GH, growth hormone; GHR, growth hormone receptor; IGF1, insulin-like growth factor 1; IGF1R, insulin-like growth factor 1 receptor; $A M P K \alpha 2$, adenosine monophosphate-activated protein kinase catalytic subunit alpha 2; $m T O R$, mammalian target of rapamycin; TG, thyroglobulin, THRA, thyroid hormone receptor alpha.

(a)

ATP5A1 average methylation level (\%) 口CG बCHG $\triangle \mathrm{CHH}$

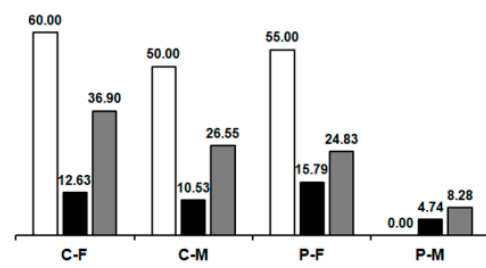

(d)

IGF1 average methylation level (\%) 口CG ॥CHG $\square \mathrm{CHH}$

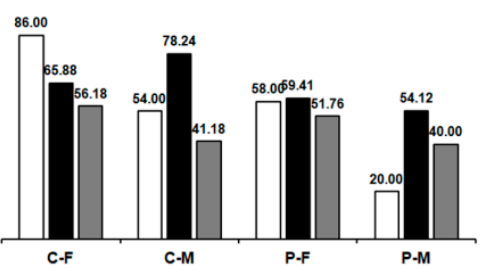

(g)

mTOR average methylation level (\%) 口CG $\triangle \mathrm{CHG}$ aCHH

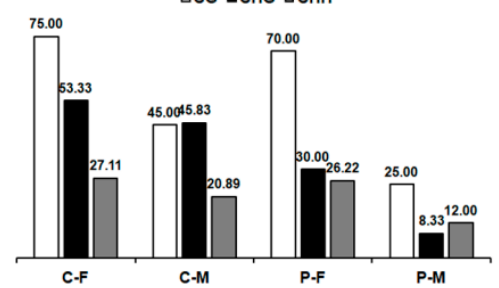

(b)

GH average methylation level (\%)

口CG $\triangle \mathrm{CHG} \triangle \mathrm{CCH}$

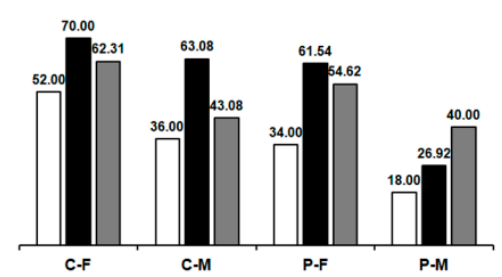

(e)

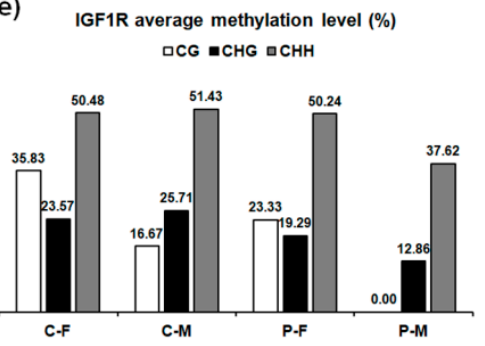

(h)

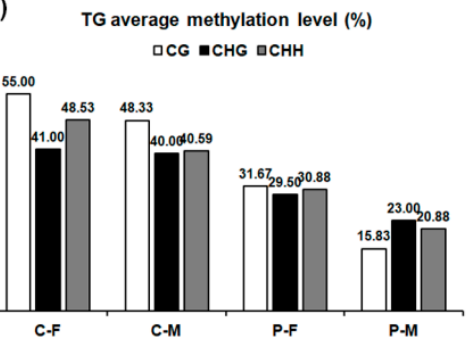

(c)

GHR average methylation level (\%) 口CG $\triangle C H G \triangle C H H$

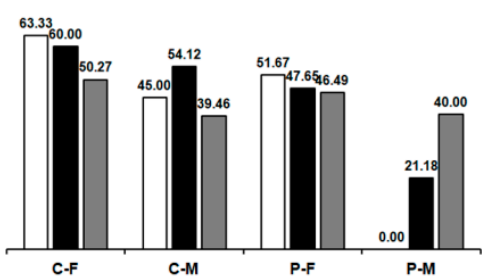

(f)

(f) AMPKa2 average methylation level (\%) वCG $\triangle \mathrm{CHG} \mathrm{\triangle CHH}$

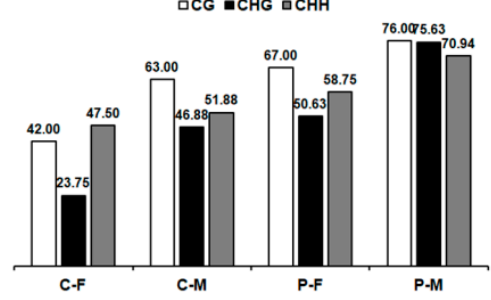

(i)

THRA average methylation level (\%) 口CG $₫ \mathrm{CHG}$ 口CHH

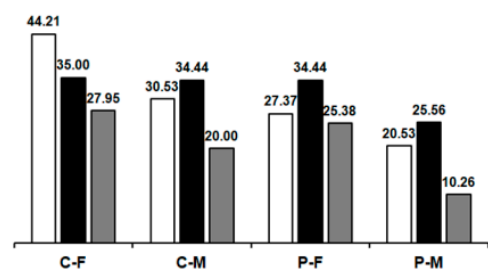

Figure 9. Average methylation levels for $\mathrm{CG}, \mathrm{CHG}$, and $\mathrm{CHH}$ sites in 90-day-old chickens. Average methylation levels in the sequenced regions of (a) ATP5A1, (b) GH, (c) GHR, (d) IGF1, (e) IGF1R, (f) $A M P K \alpha 2$, and (g) mTOR in the skeletal muscles, (h) TG, and (i) THRA in the thyroid glands.

\section{Discussion}

As an innovative technology in biological applications, non-thermal DBD plasma has recently been developed for application in the treatment of wounds, cancers, dental decays, and dermatological 
indications, and enhancement in the cell transfection efficiency, cell proliferation, and tissue regeneration [25]. In the present study, we exposed four-day-incubated fertilized eggs to plasma at $11.7 \mathrm{kV}$ for $2 \mathrm{~min}$, which was used as the optimal treatment condition in respect of highest growth rate in chickens. As shown, higher potential plasma $(27.6 \mathrm{kV})$ produced inhibitory effects on chicken growth parameters. Our previous study confirmed that high doses of non-thermal plasma exposure resulted in chicken embryonic death but appropriate treatment promoted chicken embryonic development during the early stage of incubation [4]. The findings that low-intensity plasma enhanced cell proliferation $[1,8]$ and limb growth [15] but high doses resulted in anti-proliferation [7,9] are supported by the present study leading to the conclusion that an appropriate plasma treatment should be optimized for promoting the chicken growth.

Thyroid hormones play an important role in the skeletal cell differentiation and growth [26]. DNA hypomethylation generally activates gene transcription [19] but hypermethylation suppresses gene expression [20], which mediate body mass index in the development process [27]. We found optimal plasma treatment up-regulated the mRNA expression of TG, TPO, and THRs with hypomethylation levels of TG and THRA in the thyroid glands, resulting in significant increases of serum T3, T4, FT3, and FT4, which contribute to stimulate the energy production and protein synthesis. In this study, plasma treatment enhanced serum GH and IGF1 levels, which contribute to improve the energy metabolism and protein synthesis for muscle and bone growth in poultry [28,29], but reduced serum IGFBP2 and its protein level in the skeletal muscles, which inhibit cell growth by preventing IGF1 binding to its receptor [29], through increasing the GH and IGF1 mRNA expression and decreasing the IGFBP2 mRNA expression. In addition, plasma treatment up-regulated the GHR mRNA level, IGF1R mRNA and its demethylation levels, and POU1F1 mRNA level that stimulates GH synthesis [30] in the skeletal muscles. These findings inferred that non-thermal plasma treatment stimulated a signaling cascade in the GH-IGF1 and thyroid hormones by regulating the demethylation levels of TG, THRA, GH, GHR, IGF1, and IGF1R, for the improvement of chicken growth.

GH-IGF1 signaling and thyroid hormones stimulate the muscle mitochondrial metabolism by increasing the oxidative enzyme activity and ATP production [31-33]. In this study, plasma treatment increased the number of mitochondria that contribute to increase the ATP production and energy metabolism [34] and respiratory complex activity that is a major contributor to the whole-body respiration and energy expenditure [35] in the skeletal muscles of chickens. In addition, plasma treatment improved the ATP production through increasing the ATP synthase subunit mRNA expression with a hypomethylation level of ATP5A1 and ATP5A protein. Furthermore, high concentrations of ATP inactivate AMPK, which contributes to activate mTOR pathway [36], resulting in the improvement of energy metabolism [37]. In this study, the increased daily gain of chickens exposed to plasma revealed a strong signaling correlation between the activated state of mTOR phosphorylation and opposed p-AMPK. Therefore, plasma treatment improves the ATP production and energy metabolism, which are regulated by the signaling cascade in GH-IGF1 and thyroid hormones, the increase in ATP5A1 demethylation, and the AMPK-mTOR signaling pathway.

Mitochondrial respiratory chain produces cellular ROS [38] and influences the physiological levels of ROS in the plasma-induced oxidative stress [39]. The balance between ROS production and scavenging activity which can be regulated by the catabolism in antioxidant enzymes $[12,40,41]$ influences the cell proliferation and differentiation $[8,13]$. Our study found optimal plasma treatment controlled intracellular ROS relatively low and significantly reduced MDA activity, which were mediated by up-regulating antioxidant enzyme levels of SOD, CAT, and GPx and PRDX mRNA expression and PRDX3 protein levels. Thyroid hormones can increase antioxidant defense system in different tissues [42] and GH-IGF1 signaling also can increase antioxidant enzyme activity [43,44]. Our findings revealed that the appropriate non-thermal plasma treatment regulates ROS balance for improving the chicken growth through influencing the mitochondrial respiratory complex activity and up-regulating the antioxidant enzyme activity which was mediated by thyroid hormones and GH-IGF. 
This study found plasma-treated male chickens significantly grew faster than plasma-treated females. Sex differences at the DNA methylation which are associated with differential gene expression and metabolism [23] have previously been studied in skeletal muscles [22]. Females tend to have greater DNA methylation levels than males on both the allosomes and the autosomes [24]. In this study, demethylation level increase of the growth and hormone biosynthesis-related genes in the male chickens after plasma exposure were greater than those in females, and were correlated with greater mRNA expression levels of those genes in males because the demethylation has been associated with the transcriptional activation of selected imprinted genes [45], resulting in greater serum hormone levels, ATP levels, and protein expressions in skeletal muscles of male chickens, thereby inducing faster growth of males than of females after plasma treatment.

\section{Materials and Methods}

\subsection{Plasma Treatment and Chicken Growth}

This study was carried out in strict accordance with the Animal Care and Use Committee of Jeju National University (approval number: 2016-0022, 22 January 2016) and the Institutional Committee for Ethics in Animal Experiments of Jeju National University. Artificial insemination was performed twice per week with semen collected from the cockerels (Korean native chicken, commercially used for broiler) which were raised at a chicken farm in Jeju National University, Jeju, Republic of Korea. Fertilized eggs (70 eggs for each group) obtained from hens (Hyline brown chicken, layer) were incubated at $37.5^{\circ} \mathrm{C}$ with a $45-65 \%$ relative humidity and rotated $90^{\circ}$ every $2 \mathrm{~h}$. Four-day-incubated eggs were kept in the plasma reactor (Figure 1), exposing at different intensity and time following our previously described method $[3,4]$. Briefly, the non-thermal DBD plasma reactor had two disk-shaped electrodes $(140 \mathrm{~mm})$ and a glass dielectric barrier $(5 \mathrm{~mm})$ (Figure 1). Nineteen needles with a $2 \mathrm{~mm}$ thickness and $5 \mathrm{~mm}$ length were distributed on the surface of upper electrode. The gap between the needle tip and the eggshell near to the blastoderm was approximately $10 \mathrm{~mm}$. Operating frequency of high voltage alternating current was $60 \mathrm{~Hz}$. Argon flow rate was $2 \mathrm{~L} / \mathrm{min}$. The voltage was detected using a high voltage probe $(1000 \times$, P6015, Tektronix, Beaverton, OR, USA) and recorded by a digital oscilloscope (TBS1064, Tektronix). Plasma-treated fertilized eggs were incubated for 21 days and hatched out with a hatchability of approximately $80 \%$. Chickens were housed in individual cages under the same environment conditions and given free access to equal amount of water and basic feed. Commercial crumbles (containing $18.00 \%$ crude protein, $2.50 \%$ crude fat, $7.00 \%$ crude fiber, $0.85 \%$ lysine, $0.25 \%$ methionine, $1.00 \%$ calcium, $0.70 \%$ phosphorus, and $0.50 \%$ salt) were used for feeding chicks aged at day 1 to 8 weeks. Commercial pellet feeds (containing 17.00\% crude protein, $2.50 \%$ crude fat, $8.00 \%$ crude fiber, $0.40 \%$ lysine, $0.25 \%$ methionine, $1.00 \%$ calcium, $0.40 \%$ phosphorus, and $0.50 \%$ salt) were used for feeding adolescent chickens aged at 8 weeks to 13 weeks. There were no differences in feed intake for each group. Twenty fasted females and 20 males in each group were randomly used for measuring body weight on days 0 (the first day after hatching out), 30, 60, and 90 . The 90-day-old chickens were photographed using a digital camera. The daily gain was calculated by dividing the body weight gain (final body weight - initial body weight) by the time period. The tibia length of chickens was measured. There was no mortality during the period of this study.

\subsection{Serum Hormones, ATP, ROS, and Antioxidant Enzyme Analyses}

The sera of chickens (10 females and 10 males in each group) on days 30, 60, and 90 were collected through wing vein and centrifuged for $20 \mathrm{~min}$ at $1000 \times \mathrm{g}$. Serum T3, T4, FT3, FT4, GH, IGF1, and IGFBP2 levels were detected following our previously described method [3]. Tissues obtained from the heart, liver, gizzard, intestine, and skeletal muscle of 90-day-old chickens after euthanasia were homogenized in $0.1 \%$ sodium dodecyl sulfate dissolved in PBS $(0.05 \mathrm{~mol} / \mathrm{L}, \mathrm{pH} 7.4)$. The supernatants were collected after centrifuging for $10 \mathrm{~min}$ at $12,000 \times \mathrm{g}$. The protein concentration was measured using the bicinchoninic acid protein assay kit (Sigma-Aldrich, St. Louis, MO, USA). The serum and 
tissue homogenate supernatant were analyzed for ATP, SOD, CAT, GPx, ROS, and MDA concentrations following our previously described method [2-4].

\subsection{Transmission Electron Microscopy and Mitochondrial Respiratory Enzyme Analyses}

Small blocks of skeletal muscles of 90 -day-old male chickens were placed in a mixture of $2.5 \%$ glutaraldehyde in PBS $(0.05 \mathrm{~mol} / \mathrm{L}, \mathrm{pH} 7.4)$ for $24 \mathrm{~h}$ at $4{ }^{\circ} \mathrm{C}$. Muscle blocks were subsequently post-fixed in $1 \%$ osmium tetroxide for $1 \mathrm{~h}$, dehydrated in acetone, and embedded in Epon Araldite. Ultrathin sections (50-70 $\mathrm{nm}$ ) were cut and mounted on copper grids, stained with uranyl acetate and lead citrate, and then photographed using the MegaView Soft Imaging System (Olympus, Tokyo, Japan) at $120 \mathrm{kV}$. The mitochondria of skeletal muscles obtained from 90-day-old male chickens were isolated and purified using Qproteome Mitochondria Isolation Kit (QIAGEN, Valencia, CA, USA) according to the manufacturer's protocol. The mitochondrial respiratory enzyme concentrations were detected as our previously described method [2].

\subsection{RT-PCR Analysis}

Total RNA was isolated and purified from skeletal muscles and thyroid glands of 90-day-old chickens using TRIzol Reagent (Invitrogen, Thermo Fisher Scientific, Waltham, MA, USA). cDNA synthesis was performed using TOPscript ${ }^{\mathrm{TM}}$ RT DryMIX (dT18) (Enzynomics, Daejeon, Korea). RT-PCR analysis was performed using Prime Taq Premix $(2 \times)$ (GENETBIO, Yuseong-gu, Daejeon, Korea), and EvaGreen Dye (Biotium, Hayward, CA, USA) according to the manufacturer's instructions. Primer sequences for RT-PCR are shown in Table 3. mRNA relative expression levels were normalized to the housekeeping gene ( $\beta$-actin) and calculated using the $2^{-\Delta \Delta C t}$ method.

Table 3. Primer sequences for RT-PCR.

\begin{tabular}{cccccl}
\hline Gene & $\begin{array}{c}\text { Sequence } \\
\text { Number }\end{array}$ & $\begin{array}{c}\text { Sequence } \\
\text { Position }\end{array}$ & $\begin{array}{c}\text { Product } \\
\text { Length } \mathbf{( b p )}\end{array}$ & $\begin{array}{c}\text { Annealing } \\
\text { Temperature }\left({ }^{\circ} \mathbf{C}\right)\end{array}$ & Sequence $\left(5^{\prime}\right.$ to3 $\left.{ }^{\prime}\right)$ \\
\hline$\beta$-actin & NM_205518.1 & $625-818$ & 194 & 57 & $\begin{array}{l}\text { F: GTGCGTGACATCAAGGAGAAGC } \\
\text { R: CCACAGGACTCCATACCCAAGA }\end{array}$ \\
\hline ATP5A1 & NM_204286.1 & $1207-1364$ & 158 & 57 & $\begin{array}{l}\text { F: GGTATCCGTCCAGCCATCAA } \\
\text { R: GCATCCAAATCAGACCCAAACT }\end{array}$ \\
\hline ATP5B & NM_001031391.2 & $482-637$ & 156 & 57 & $\begin{array}{l}\text { F: GCCCCATCACAACGAAACAG } \\
\text { R: CGCCTCCAAACAAACCAATC }\end{array}$ \\
\hline ATP5C1 & NM_001278096.1 & $272-411$ & 140 & 57 & $\begin{array}{l}\text { F: ATTAAGGCACCCGAGGACAA } \\
\text { R: ACTTCCTTCCCTGCATTGGA }\end{array}$ \\
\hline ATP5F1 & XM_417993.4 & $437-644$ & 208 & 57 & $\begin{array}{l}\text { F: CATTGGAGACTGCCATTGAGG } \\
\text { R: TGATCTTGCTCTTTCTGACGCTT }\end{array}$ \\
\hline ATP5G1 & XM_001233602.3 & $287-536$ & 250 & 57 & $\begin{array}{l}\text { F: CAGGAGCAGGTATTGGGACA } \\
\text { R: TTGTCAGTCTGGAACGCTCT }\end{array}$ \\
\hline ATP5G3 & NM_001277855.1 & $141-288$ & 148 & 57 & $\begin{array}{l}\text { F: CCAAAACGCTGTCTCCCAAC } \\
\text { R: ACCGAAGACCGTTCCAATACC }\end{array}$ \\
\hline ATP5H & XM_001232598.3 & $332-551$ & 220 & 57 & $\begin{array}{l}\text { F: CTGAAGGTCCCTGAACCAGT } \\
\text { R: ACTTCTCCCTGTCCAGTCTG }\end{array}$ \\
\hline ATP5I & NM_001097534.2 & $74-240$ & 167 & 57 & $\begin{array}{l}\text { F: TCTCGCCCCTCATCAAGTTC } \\
\text { R: TGCCAGTTCCTTTGCAATCC }\end{array}$ \\
\hline ATP5J & XM_004938370.1 & $58-197$ & 140 & 58 & $\begin{array}{l}\text { F: CACTTGCGGAGAAACATCGGT } \\
\text { R: CCTACATCAACAGGTCCTCCAGC }\end{array}$ \\
\hline ATP5J2 & NM_001257200.1 & $170-263$ & 94 & 57 & $\begin{array}{l}\text { F: GCCTCGGTGGTATCAGTATGGT } \\
\text { R: TACTTCCTGCGGCGGTCAT }\end{array}$ \\
\hline ATP5L & XM_015298211 & $250-377$ & 128 & 57 & $\begin{array}{l}\text { F: CCATGGTCAGGAGCTTTCAG } \\
\text { R: GCCTCGTTTGCCTATGATCTC }\end{array}$ \\
\hline
\end{tabular}


Table 3. Cont.

\begin{tabular}{|c|c|c|c|c|c|}
\hline Gene & $\begin{array}{l}\text { Sequence } \\
\text { Number }\end{array}$ & $\begin{array}{l}\text { Sequence } \\
\text { Position }\end{array}$ & $\begin{array}{c}\text { Product } \\
\text { Length (bp) }\end{array}$ & $\begin{array}{c}\text { Annealing } \\
\text { Temperature }\left({ }^{\circ} \mathrm{C}\right)\end{array}$ & Sequence $\left(5^{\prime}\right.$ to $\left.3^{\prime}\right)$ \\
\hline ATP5S & NM_001277562.1 & $46-279$ & 234 & 57 & $\begin{array}{l}\text { F: TCCCCTTCCСCTTTCTTTCC } \\
\text { R: CATAGCCTTGATAGCGCACC }\end{array}$ \\
\hline GH & NM_204359.2 & $104-284$ & 181 & 57 & $\begin{array}{l}\text { F: TGTTTGCCAACGCTGTGCT } \\
\text { R: TTCTGCTGGGCGTCATCCT }\end{array}$ \\
\hline GHR & NM_001001293.1 & 1070-1299 & 230 & 57 & $\begin{array}{l}\text { F: GTCACACAGTTGCTTGGGAG } \\
\text { R: TATGCGGCTGTTGGGTATCT }\end{array}$ \\
\hline IGF1 & NM_001004384.2 & $188-316$ & 129 & 58 & $\begin{array}{l}\text { F: AGTTCGTATGTGGAGACAGAGGC } \\
\text { R: CCAGCCTCCTCAGGTCACAAC }\end{array}$ \\
\hline$I G F 1 R$ & NM_205032.1 & 2961-3114 & 154 & 57 & $\begin{array}{l}\text { F: TTGTGCTCCCCATTGCTTTC } \\
\text { R: GGAACGTACACATCCGAAGC }\end{array}$ \\
\hline IGFBP2 & NM_205359.1 & $582-793$ & 212 & 57 & $\begin{array}{l}\text { F: TCACAACCACGAGGACTCAAAG } \\
\text { R: GCTGCCCATTCACCGACAT }\end{array}$ \\
\hline POU1F1 & NM_204319.1 & $560-754$ & 195 & 57 & $\begin{array}{l}\text { F: ATGTTGGCGAAGCACTGGC } \\
\text { R: GCTTCCTCTTCCGCTCATTCA }\end{array}$ \\
\hline$A M P K \alpha 2$ & NM_001039605.1 & $726-943$ & 218 & 57 & $\begin{array}{l}\text { F: GGAGGCGTGTTTTACATCCC } \\
\text { R: AACTTCTCACAGACCTCCCG }\end{array}$ \\
\hline$A M P K \beta 2$ & NM_001044662.1 & $435-661$ & 227 & 57 & $\begin{array}{l}\text { F: CCAGTGTTTTCAGCTCCCAC } \\
\text { R: GAGGTCCAGGATAGCGACAA }\end{array}$ \\
\hline$A M P K \gamma 3$ & NM_001031258.2 & $183-320$ & 138 & 57 & $\begin{array}{l}\text { F: GCTGGAACCCGACAACAATT } \\
\text { R: GCCTTCTTGATCTCCAGGGT }\end{array}$ \\
\hline mTOR & XM_417614.4 & 119-309 & 191 & 57 & $\begin{array}{l}\text { F: TGAAGGGGTCAAGGCAATCC } \\
\text { R: GGCGAGCAGTGGTTGTGGAT }\end{array}$ \\
\hline PRDX1 & NM_001271932.1 & $358-545$ & 188 & 56 & $\begin{array}{l}\text { F: ACAAGGTGGTTTGGGCACTA } \\
\text { R: TCTCATCAACAGAACGGCCA }\end{array}$ \\
\hline PRDX3 & XM_426543.5 & $414-551$ & 138 & 56 & $\begin{array}{l}\text { F: TTTCACCTTTGTGTGCCCCA } \\
\text { R: TTGCGCGGGGTATTTATCCA }\end{array}$ \\
\hline PRDX4 & XM_001233999.3 & $595-733$ & 139 & 56 & $\begin{array}{l}\text { F: TGCACTTAGGGGCCTTTTCA } \\
\text { R: TTCTCCATGCTTGTCCGTGT }\end{array}$ \\
\hline PRDX6 & NM_001039329.2 & $189-340$ & 152 & 58 & $\begin{array}{l}\text { F: TGAGTTCAGCAAACGCAACG } \\
\text { R: GCTCTCGGTCCTTATCAGCG }\end{array}$ \\
\hline$T G$ & XM_015283114.1 & $2812-2966$ & 155 & 57 & $\begin{array}{l}\text { F: GCAGCTTTCCAAACCTTCAG } \\
\text { R: GGCTCCAGCACAGAGAAAAC }\end{array}$ \\
\hline TPO & XM_015284944.1 & $1872-2075$ & 204 & 58 & $\begin{array}{l}\text { F: TGACGCTCAAAAGCATGAAC } \\
\text { R: TGCTTTGGTGTTCCACACAT }\end{array}$ \\
\hline THRA & NM_205313.1 & $355-636$ & 282 & 57 & $\begin{array}{l}\text { F: AAGCGCAAAAGAAAGAGCAG } \\
\text { R: CACGGAGATGCACTTCTTGA }\end{array}$ \\
\hline THRB & NM_205447.2 & $976-1150$ & 175 & 58 & $\begin{array}{l}\text { F: TTTCCTCCTGGCATTTGAAC } \\
\text { R: CAGGAACAATGGAGGGAAGA }\end{array}$ \\
\hline
\end{tabular}

ATP5B, ATP synthase, $\mathrm{H}^{+}$transporting, mitochondrial $\mathrm{F} 1$ complex, beta polypeptide; ATP5C1, ATP synthase, $\mathrm{H}^{+}$transporting, mitochondrial F1 complex, gamma polypeptide 1; ATP5F1, ATP synthase, $\mathrm{H}^{+}$transporting, mitochondrial Fo complex, subunit B1; ATP5G1, ATP synthase, $\mathrm{H}^{+}$transporting, mitochondrial Fo complex, subunit C1; ATP5G3, ATP synthase, $\mathrm{H}^{+}$transporting, mitochondrial Fo complex, subunit $\mathrm{C} 3$; ATP5H, ATP synthase, $\mathrm{H}^{+}$transporting, mitochondrial Fo complex, subunit D; ATP5I, ATP synthase, $\mathrm{H}^{+}$transporting, mitochondrial Fo complex, subunit E; ATP5I, ATP synthase, $\mathrm{H}^{+}$transporting, mitochondrial Fo complex, subunit F6; ATP5J2, ATP synthase, $\mathrm{H}^{+}$transporting, mitochondrial Fo complex, subunit F2; ATP5L, ATP synthase, $\mathrm{H}^{+}$transporting, mitochondrial Fo complex, subunit G; ATP5S, ATP synthase, $\mathrm{H}^{+}$transporting, mitochondrial Fo complex, subunit S; IGFBP2, insulin-like growth factor binding protein 2; POU1F1, POU class 1 homeobox 1; $A M P K \beta 2$, adenosine monophosphate-activated protein kinase non-catalytic subunit beta 2; $A M P K \gamma 3$, adenosine monophosphate-activated protein kinase non-catalytic subunit gamma 3; PRDX, peroxiredoxin; TPO, thyroid peroxidase; THRB, thyroid hormone receptor beta.

\subsection{Methylation Sequencing}

Genomic DNA was isolated and purified from skeletal muscles and thyroid glands of 90-day-old chickens using an AllPrep DNA/RNA Micro Kit (QIAGEN). Sodium bisulfite conversion bisulfite-sequencing PCR (BSP) was performed using the EpiTech Bisulfite Kit (QIAGEN). BSP primers were designed using MethPrimer (http:/ / www.urogene.org/methprimer/) (Table 4). BSP products 
were purified, ligated, and transformed using the pGEM-T Easy Vector system I (Promega, Madison, WI, USA). Plasmids containing the target DNA were confirmed and sequenced as previously described method [2,5]. The cytosine methylation was analyzed using CyMATE software. The total methylation ratio and average methylation levels for $\mathrm{CG}, \mathrm{CHG}$ and $\mathrm{CHH}$ were calculated as previously described method $[2,5]$.

Table 4. Primer sequences for bisulfite-sequencing PCR.

\begin{tabular}{|c|c|c|c|c|c|c|}
\hline Gene & $\begin{array}{l}\text { Chromosome } \\
\text { Location }\end{array}$ & $\begin{array}{l}\text { Sequence } \\
\text { Position }\end{array}$ & $\begin{array}{l}\text { Product } \\
\text { Length (bp) }\end{array}$ & $\begin{array}{c}\text { Annealing } \\
\text { Temperature } \\
\left({ }^{\circ} \mathrm{C}\right)\end{array}$ & Sequence $\left(5^{\prime}\right.$ to $\left.3^{\prime}\right)$ & $\begin{array}{c}\text { Expected } \\
\text { No. of } \\
\text { CpGs }\end{array}$ \\
\hline ATP $5 A 1$ & Z & $1082-1292$ & 211 & 55 & $\begin{array}{l}\text { F: GAGGTTTTTTGATTGTTTTGTTTGT } \\
\text { R: CCTACCACCTATTTCATTACCCTAAT }\end{array}$ & 4 \\
\hline GH & 27 & $458-611$ & 154 & 53 & $\begin{array}{l}\text { F: AAGAAGGGATTTAAGTTTTGATGAG } \\
\text { R: TCCTTCTTAAAACAAAACAACAAAC }\end{array}$ & 10 \\
\hline GHR & Z & $436-768$ & 333 & 53 & $\begin{array}{l}\text { F: GTTAAATTGGGATTTATGGGGATAT } \\
\text { R: CAACAACTAAAAACCAAAAAAACTC }\end{array}$ & 6 \\
\hline IGF1 & 1 & $413-661$ & 249 & 53 & $\begin{array}{l}\text { F: TTGAGTTGGTTGATGTTTTTTAGTT } \\
\text { R: TCAAATACACTTCCTTTTATACTTTTAACA }\end{array}$ & 5 \\
\hline$I G F 1 R$ & 10 & $308-554$ & 247 & 52 & $\begin{array}{l}\text { F: GTTGAGGGTTTTTTTTAGATTTTGTT } \\
\text { R: TTATATTCCTCAAATTATAAAACCC }\end{array}$ & 12 \\
\hline$A M P K \alpha 2$ & 8 & $233-463$ & 231 & 52 & $\begin{array}{l}\text { F: AGAAATTTAAAATTTGAAATTTTTT } \\
\text { R: AAATCCCTATAAACAACCATATATC }\end{array}$ & 10 \\
\hline$m T O R$ & 21 & $1690-1890$ & 201 & 52 & $\begin{array}{l}\text { F: ATATTTAGGATGGGTTGTTGAAAAT } \\
\text { R: AAATCAAAAAATACCCTTCAAACTC }\end{array}$ & 4 \\
\hline TG & 2 & 2943-3144 & 202 & 53 & $\begin{array}{l}\text { F: TATTGTTTTTTTTGTGTTGGAGTTT } \\
\text { R: TATATATCCCCATCAATATCACAC }\end{array}$ & 12 \\
\hline THRA & 27 & $145-385$ & 241 & 51 & $\begin{array}{l}\text { F: GGGATGTTGTAGGGAGTTTAGTATT } \\
\text { R: CCAAACATTAACTACTCTTTCTTTTAC }\end{array}$ & 19 \\
\hline
\end{tabular}

\subsection{Western Blotting}

Skeletal muscles of 90-day-old chickens were cut into small pieces and resuspended in RIPA lysis and extraction buffer (Thermo Fisher Scientific) for $30 \mathrm{~min}$ at $4{ }^{\circ} \mathrm{C}$ prior to centrifugation for $10 \mathrm{~min}$ at $12,000 \times \mathrm{g}$. The protein concentration was measured using a bicinchoninic acid protein assay kit (Sigma-Aldrich) and adjusted to equal protein concentration. Western blotting was performed as our previously described method $[2,4,6,46]$. The following antibodies were used: anti-phospho-AMPK $\alpha$ (Thr172, p-AMPK $\alpha$; rabbit polyclonal; Cell Signaling Technology, Beverly, MA, USA; 1:1000), anti-AMPK $\alpha$ (rabbit polyclonal; Cell Signaling Technology; 1:1000), anti-phospho-mTOR (Ser2448, p-mTOR; rabbit monoclonal; Cell Signaling Technology; 1:1000), anti-mTOR (rabbit polyclonal; Cell Signaling Technology; 1:1000), anti-ATP5A (rabbit polyclonal; Abcam, Cambridge, UK; 1:250), anti-GHR (rabbit polyclonal; Bioss, Woburn, MA, USA; 1:500), anti-IGFBP2 (rabbit polyclonal; Bioss; 1:500), anti-PRX III (mouse monoclonal; Santa Cruz Biotechnology, Dallas, TX, USA; 1:200), anti-beta actin (rabbit polyclonal; Bioss; 1:1000), goat anti-mouse (Santa Cruz Biotechnology; 1: 5000), and goat anti-rabbit (Abcam; 1: 5000) IgG coupled to horseradish peroxidase conjugate. Band intensity was quantified using the ImageJ software (National Institutes of Health, Bethesda, MA, USA). The densitometric value of each $\mathrm{p}-\mathrm{AMPK} \alpha, \mathrm{AMPK} \alpha, \mathrm{p}-\mathrm{mTOR}$, and mTOR band was normalized to the $\beta$-actin before calculating the $\mathrm{p}-\mathrm{AMPK} \alpha / \mathrm{AMPK} \alpha$ and $\mathrm{p}-\mathrm{mTOR} / \mathrm{mTOR}$ ratios. The densitometric values of the ATP5A, GHR, IGFBP2, and PRDX3 bands were also normalized to the relevant $\beta$-actin.

\subsection{Statistical Analysis}

Data are represented as mean \pm standard deviation (SD) of three independent measurements. Statistical analyses were performed using the Statistical Package for the Social Sciences (SPSS version 16.0). Statistically significant differences were determined by the one-way ANOVA with a Fisher's least significant difference (LSD) test. The values were considered significantly different at $p<0.05$. 


\section{Conclusions}

Four-day-incubated fertilized eggs treated with non-thermal plasma at $11.7 \mathrm{kV}$ for 2 min have the highest growth rate in chickens after hatching. Especially, plasma-treated male chickens conspicuously grow faster than females. The growth-promoting effect of plasma in chickens was regulated by ROS homeostasis and the significant improvement of growth metabolism by increasing GH-IGF1 and their receptors expression, and thyroid hormones and ATP levels, which resulted from the regulation of demethylation levels of growth and hormone biosynthesis-related genes in the skeletal muscles and thyroid glands. Our findings provide an innovative approach that non-thermal DBD plasma treatment of fertilized eggs before hatching as a potentially viable and safe strategy for improving the growth rate in chickens. We have a bold hypothesis that the treatment of optimal plasma on embryonic stage may provide a potential practical application in raising animal productivity.

Supplementary Materials: Supplementary Materials can be found at http:/ /www.mdpi.com/1422-0067/19/8/ $2301 /$ s1.

Author Contributions: Conceptualization, J.J.Z., Y.S.M. and D.K.J.; Methodology, J.J.Z., X.Z.W., T.K., D.L.H. and N.C.; Software, N.K., T.Y.K., M.G. (Mrinmoy Ghosh) and M.G. (Meeta Gera); Validation, S.B.L., S.B.K., Y.S.M. and D.K.J.; Formal Analysis, J.J.Z., Y.S.M. and D.K.J.; Investigation, J.J.Z.; Resources, S.J.L., W.S.L. and S.B.K.; Data Curation, J.J.Z., X.Z.W., Y.S.M. and D.K.J.; Writing-Original Draft Preparation, J.J.Z.; Writing-Review \& Editing, D.K.J.; Visualization, J.J.Z., Y.S.M. and D.K.J.; Supervision, D.K.J.; Project Administration, D.K.J.; Funding Acquisition, D.K.J.

Funding: This research was supported by Basic Science Research Program through the National Research Foundation of Korea (NRF) funded by the Ministry of Education (2016R1A6A1A03012862).

Acknowledgments: We thank National Fusion Research Institute of Korea (NRFI) for providing the R\&D Program of "Plasma Advanced Technology for Agriculture and Food (Plasma Farming)". The authors are thankful to the China Scholarship Council for providing a scholarship fund to the first author.

Conflicts of Interest: The authors declare no conflict of interest.

\section{Abbreviations}

$\begin{array}{ll}\text { DBD } & \text { Dielectric barrier discharge } \\ \text { ROS } & \text { Reactive oxygen species } \\ \text { ADG } & \text { Average daily gain } \\ \text { T3 } & \text { Triiodothyronine } \\ \text { T4 } & \text { Thyroxine } \\ \text { FT3 } & \text { Free triiodothyronine } \\ \text { FT4 } & \text { Free thyroxine } \\ \text { GH } & \text { Growth hormone } \\ \text { IGF1 } & \text { Insulin-like growth factor 1 } \\ \text { IGFBP2 } & \text { Insulin-like growth factor binding protein 2 } \\ \text { ATP } & \text { Adenosine triphosphate } \\ \text { SOD } & \text { Superoxide dismutase } \\ \text { CAT } & \text { Catalase } \\ \text { GPx } & \text { Glutathione peroxidase } \\ \text { MDA } & \text { Malondialdehyde } \\ \text { NADH } & \text { Nicotinamide adenine dinucleotide hydrogen } \\ \text { GHR } & \text { Growth hormone receptor } \\ \text { IGF1R } & \text { Insulin-like growth factor 1 receptor } \\ \text { POU1F1 } & \text { POU class 1 homeobox 1 } \\ \text { mTOR } & \text { Mammalian target of rapamycin } \\ \text { AMPK } & \text { Adenosine monophosphate-activated protein kinase } \\ \text { PRDXs } & \text { Peroxiredoxins } \\ \text { TG } & \text { Thyroglobulin } \\ \text { TPO } & \text { Thyroid peroxidase } \\ \end{array}$


THRs Thyroid hormone receptors

BSP Bisulfite-sequencing PCR

SD Standard deviation

LSD Fisher's least significant difference

\section{References}

1. Kalghatgi, S.; Kelly, C.M.; Cerchar, E.; Torabi, B.; Alekseev, O.; Fridman, A.; Friedman, G.; Azizkhan-Clifford, J. Effects of non-thermal plasma on mammalian cells. PLoS ONE 2011, 6, e16270. [CrossRef] [PubMed]

2. Zhang, J.J.; Do, H.L.; Chandimali, N.; Lee, S.B.; Mok, Y.S.; Kim, N.; Kim, S.B.; Kwon, T.; Jeong, D.K. Non-thermal plasma treatment improves chicken sperm motility via the regulation of demethylation levels. Sci. Rep. 2018, 8, 7576. [CrossRef] [PubMed]

3. Zhang, J.J.; Huynh, D.L.; Chandimali, N.; Kang, T.Y.; Kim, N.; Mok, Y.S.; Kwon, T.; Jeong, D.K. Growth and male reproduction improvement of non-thermal dielectric barrier discharge plasma treatment on chickens. J. Phys. D Appl. Phys. 2018, 51, 205201. [CrossRef]

4. Zhang, J.J.; Jo, J.O.; Huynh, D.L.; Ghosh, M.; Kim, N.; Lee, S.B.; Lee, H.K.; Mok, Y.S.; Kwon, T.; Jeong, D.K. Lethality of inappropriate plasma exposure on chicken embryonic development. Oncotarget 2017, 8, 85642-85654. [CrossRef] [PubMed]

5. Zhang, J.J.; Jo, J.O.; Huynh, D.L.; Mongre, R.K.; Ghosh, M.; Singh, A.K.; Lee, S.B.; Mok, Y.S.; Hyuk, P.; Jeong, D.K. Growth-inducing effects of argon plasma on soybean sprouts via the regulation of demethylation levels of energy metabolism-related genes. Sci. Rep. 2017, 7, 41917. [CrossRef] [PubMed]

6. Zhang, J.J.; Wang, X.Z.; Luong Do, H.; Chandimali, N.; Kang, T.Y.; Kim, N.; Ghosh, M.; Lee, S.B.; Mok, Y.S.; Kim, S.B.; et al. MicroRNA-7450 regulates non-thermal plasma-induced chicken Sertoli cell apoptosis via adenosine monophosphate-activated protein kinase activation. Sci. Rep. 2018, 8, 8761. [CrossRef] [PubMed]

7. Kieft, I.E.; Kurdi, M.; Stoffels, E. Reattachment and apoptosis after plasma-needle treatment of cultured cells. IEEE Trans. Plasma Sci. 2006, 34, 1331-1336. [CrossRef]

8. Kalghatgi, S.; Friedman, G.; Fridman, A.; Clyne, A.M. Endothelial cell proliferation is enhanced by low dose non-thermal plasma through fibroblast growth factor-2 release. Ann. Biomed. Eng. 2010, 38, 748-757. [CrossRef] [PubMed]

9. Nakai, N.; Fujita, R.; Kawano, F.; Takahashi, K.; Ohira, T.; Shibaguchi, T.; Nakata, K.; Ohira, Y. Retardation of C2C12 myoblast cell proliferation by exposure to low-temperature atmospheric plasma. J. Physiol. Sci. 2014, 64, 365-375. [CrossRef] [PubMed]

10. Kuchenbecker, M.; Bibinov, N.; Kaemlimg, A.; Wandke, D.; Awakowicz, P.; Viol, W. Characterization of DBD plasma source for biomedical applications. J. Phys. D Appl. Phys. 2009, 42, 045212. [CrossRef]

11. Lin, A.; Truong, B.; Patel, S.; Kaushik, N.; Choi, E.H.; Fridman, G.; Fridman, A.; Miller, V. Nanosecond-pulsed DBD plasma-generated reactive oxygen species trigger immunogenic cell death in A549 lung carcinoma cells through intracellular oxidative stress. Int. J. Mol. Sci. 2017, 18, 966. [CrossRef] [PubMed]

12. Yan, X.; Xiong, Z.; Zou, F.; Zhao, S.; Lu, X.; Yang, G.; He, G.; Ostrikov, K. Plasma-induced death of HepG2 cancer cells: Intracellular effects of reactive species. Plasma Process. Polym. 2011, 9, 59-66. [CrossRef]

13. Steinbeck, M.J.; Chernets, N.; Zhang, J.; Kurpad, D.S.; Fridman, G.; Fridman, A.; Freeman, T.A. Skeletal cell differentiation is enhanced by atmospheric dielectric barrier discharge plasma treatment. PLOS ONE 2013, 8, e82143. [CrossRef] [PubMed]

14. Chen, C.; Liu, Y.; Liu, R.; Ikenoue, T.; Guan, K.-L.; Liu, Y.; Zheng, P. TSC-mTOR maintains quiescence and function of hematopoietic stem cells by repressing mitochondrial biogenesis and reactive oxygen species. J. Exp. Med. 2008, 205, 2397-2408. [CrossRef] [PubMed]

15. Chernets, N.; Zhang, J.; Steinbeck, M.J.; Kurpad, D.S.; Koyama, E.; Friedman, G.; Freeman, T.A. Nonthermal atmospheric pressure plasma enhances mouse limb bud survival, growth, and elongation. Tissue Eng. Part A 2015, 21, 300-309. [CrossRef] [PubMed]

16. Kim, K.C.; Piao, M.J.; Hewage, S.R.K.M.; Han, X.I.A.; Kang, K.A.; Jo, J.O.; Mok, Y.S.; Shin, J.H.; Park, Y.; Yoo, S.J.; et al. Non-thermal dielectric-barrier discharge plasma damages human keratinocytes by inducing oxidative stress. Int. J. Mol. Med. 2016, 37, 29-38. [CrossRef] [PubMed] 
17. Blackert, S.; Haertel, B.; Wende, K.; von Woedtke, T.; Lindequist, U. Influence of non-thermal atmospheric pressure plasma on cellular structures and processes in human keratinocytes (HaCaT). J. Dermatol. Sci. 2013, 70, 173-181. [CrossRef] [PubMed]

18. Li, Q.; Li, N.; Hu, X.; Li, J.; Du, Z.; Chen, L.; Yin, G.; Duan, J.; Zhang, H.; Zhao, Y.; et al. Genome-wide mapping of DNA methylation in chicken. PLoS ONE 2011, 6, e19428. [CrossRef] [PubMed]

19. Baylin, S.B.; Esteller, M.; Rountree, M.R.; Bachman, K.E.; Schuebel, K.; Herman, J.G. Aberrant patterns of DNA methylation, chromatin formation and gene expression in cancer. Hum. Mol. Genet. 2001, 10, 687-692. [CrossRef] [PubMed]

20. Jin, B.; Li, Y.; Robertson, K.D. DNA methylation: Superior or subordinate in the epigenetic hierarchy? Genes Cancer 2011, 2, 607-617. [CrossRef] [PubMed]

21. Cao-Lei, L.; Massart, R.; Suderman, M.J.; Machnes, Z.; Elgbeili, G.; Laplante, D.P.; Szyf, M.; King, S. DNA methylation signatures triggered by prenatal maternal stress exposure to a natural disaster: Project ice storm. PLoS ONE 2014, 9, e107653. [CrossRef] [PubMed]

22. Cotton, A.M.; Lam, L.; Affleck, J.G.; Wilson, I.M.; Peñaherrera, M.S.; McFadden, D.E.; Kobor, M.S.; Lam, W.L.; Robinson, W.P.; Brown, C.J. Chromosome-wide DNA methylation analysis predicts human tissue-specific $\mathrm{X}$ inactivation. Hum. Genet. 2011, 130, 187-201. [CrossRef] [PubMed]

23. Hall, E.; Volkov, P.; Dayeh, T.; Esguerra, J.L.S.; Salö, S.; Eliasson, L.; Rönn, T.; Bacos, K.; Ling, C. Sex differences in the genome-wide DNA methylation pattern and impact on gene expression, microRNA levels and insulin secretion in human pancreatic islets. Genome Boil. 2014, 15, 522. [CrossRef] [PubMed]

24. Liu, J.; Morgan, M.; Hutchison, K.; Calhoun, V.D. A Study of the Influence of Sex on Genome Wide Methylation. PLoS ONE 2010, 5, e10028. [CrossRef] [PubMed]

25. Szili, E.J.; Hong, S.-H.; Oh, J.-S.; Gaur, N.; Short, R.D. Tracking the penetration of plasma reactive species in tissue models. Trends Biotechnol. 2018, 36, 594-602. [CrossRef] [PubMed]

26. Bassett, J.H.D.; Williams, G.R. Role of Thyroid Hormones in Skeletal Development and Bone Maintenance. Endocr. Rev. 2016, 37, 135-187. [CrossRef] [PubMed]

27. Cao-Lei, L.; Dancause, K.N.; Elgbeili, G.; Massart, R.; Szyf, M.; Liu, A.; Laplante, D.P.; King, S. DNA methylation mediates the impact of exposure to prenatal maternal stress on BMI and central adiposity in children at age $13 \frac{1}{2}$ years: Project Ice Storm. Epigenetics 2015, 10, 749-761. [CrossRef] [PubMed]

28. Veldhuis, J.D.; Roemmich, J.N.; Richmond, E.J.; Rogol, A.D.; Lovejoy, J.C.; Sheffield-Moore, M.; Mauras, N.; Bowers, C.Y. Endocrine control of body composition in infancy, childhood, and puberty. Endocr. Rev. 2005, 26, 114-146. [CrossRef] [PubMed]

29. Kita, K.; Nagao, K.; Okumura, J. Nutritional and tissue specificity of IGF-I and IGFBP-2 gene expression in growing chickens. Asian Australas. J. Anim. Sci. 2005, 18, 747-754. [CrossRef]

30. Sobrier, M.L.; Tsai, Y.C.; Perez, C.; Leheup, B.; Bouceba, T.; Duquesnoy, P.; Copin, B.; Sizova, D.; Penzo, A.; Stanger, B.Z.; et al. Functional characterization of a human POU1F1 mutation associated with isolated growth hormone deficiency: A novel etiology for IGHD. Hum. Mol. Genet. 2016, 25, 472-483. [CrossRef] [PubMed]

31. Lanni, A.; Moreno, M.; Goglia, F. Mitochondrial Actions of Thyroid Hormone; John Wiley \& Sons, Inc.: New York, NY, USA, 2011. [CrossRef]

32. Short, K.R.; Moller, N.; Bigelow, M.L.; Coenen-Schimke, J.; Nair, K.S. Enhancement of muscle mitochondrial function by growth hormone. J. Clin. Endocrinol. Metab. 2008, 93, 597-604. [CrossRef] [PubMed]

33. Troncoso, R.; Vicencio, J.M.; Parra, V.; Nemchenko, A.; Kawashima, Y.; del Campo, A.; Toro, B.; Battiprolu, P.K.; Aranguiz, P.; Chiong, M.; et al. Energy-preserving effects of IGF-1 antagonize starvation-induced cardiac autophagy. Cardiovasc. Res. 2012, 93, 320-329. [CrossRef] [PubMed]

34. Donald, V.; Judith, G.V.; Charlotte, W.P. Fundamentals of Biochemistry, 2nd ed.; John Wiley and Sons, Inc.: New York, NY, USA, 2006.

35. Zurlo, F.; Larson, K.; Bogardus, C.; Ravussin, E. Skeletal muscle metabolism is a major determinant of resting energy expenditure. J. Clin. Investig. 1990, 86, 1423-1427. [CrossRef] [PubMed]

36. Du, M.; Shen, Q.W.; Zhu, M.J.; Ford, S.P. Leucine stimulates mammalian target of rapamycin signaling in $\mathrm{C} 2 \mathrm{C} 12$ myoblasts in part through inhibition of adenosine monophosphate-activated protein kinase. J. Anim. Sci. 2007, 85, 919-927. [CrossRef] [PubMed]

37. Viollet, B.; Horman, S.; Leclerc, J.; Lantier, L.; Foretz, M.; Billaud, M.; Giri, S.; Andreelli, F. AMPK inhibition in health and disease. Crit. Rev. Biochem. Mol. Boil. 2010, 45, 276-295. [CrossRef] [PubMed] 
38. Murphy, M.P. How mitochondria produce reactive oxygen species. Biochem. J. 2009, 417, 1-13. [CrossRef] [PubMed]

39. Zhunussova, A.; Vitol, E.A.; Polyak, B.; Tuleukhanov, S.; Brooks, A.D.; Sensenig, R.; Friedman, G.; Orynbayeva, Z. Mitochondria-mediated anticancer effects of non-thermal atmospheric plasma. PLoS ONE 2016, 11, e0156818. [CrossRef] [PubMed]

40. Kaushik, N.K.; Kaushik, N.; Park, D.; Choi, E.H. Altered antioxidant system stimulates dielectric barrier discharge plasma-induced cell death for solid tumor cell treatment. PLoS ONE 2014, 9, e103349. [CrossRef] [PubMed]

41. Lukyanenko, L.M.; Skarabahatava, A.S.; Slobozhanina, E.I.; Kovaliova, S.A.; Falcioni, M.L.; Falcioni, G. In vitro effect of $\mathrm{AlCl} 3$ on human erythrocytes: Changes in membrane morphology and functionality. J. Trace Elem. Med. Biol. 2013, 27, 160-167. [CrossRef] [PubMed]

42. Wagner, M.S.; Wajner, S.M.; Maia, A.L. The role of thyroid hormone in testicular development and function. J. Endocrinol. 2008, 199, 351-365. [CrossRef] [PubMed]

43. Zhu, Z.; Mukhina, S.; Zhu, T.; Mertani, H.C.; Lee, K.O.; Lobie, P.E. p44/42 MAP kinase-dependent regulation of catalase by autocrine human growth hormone protects human mammary carcinoma cells from oxidative stress-induced apoptosis. Oncogene 2005, 24, 3774-3785. [CrossRef] [PubMed]

44. Higashi, Y.; Pandey, A.; Goodwin, B.; Delafontaine, P. Insulin-like growth factor-1 regulates glutathione peroxidase expression and activity in vascular endothelial cells: Implications for atheroprotective actions of insulin-like growth factor-1. Biochim. Biophys. Acta 2013, 1832, 391-399. [CrossRef] [PubMed]

45. Maeder, M.L.; Angstman, J.F.; Richardson, M.E.; Linder, S.J.; Cascio, V.M.; Tsai, S.Q.; Ho, Q.H.; Sander, J.D.; Reyon, D.; Bernstein, B.E.; et al. Targeted DNA demethylation and activation of endogenous genes using programmable TALE-TET1 fusion proteins. Nat. Biotechnol. 2013, 31, 1137-1142. [CrossRef] [PubMed]

46. Jiao, Z.J.; Yi, W.; Rong, Y.W.; Kee, J.D.; Zhong, W.X. MicroRNA-1285 regulates 17ß-estradiol-inhibited immature boar Sertoli cell proliferation via adenosine monophosphate-activated protein kinase activation. Endocrinology 2015, 156, 4059-4070. [CrossRef] [PubMed]

(C) 2018 by the authors. Licensee MDPI, Basel, Switzerland. This article is an open access article distributed under the terms and conditions of the Creative Commons Attribution (CC BY) license (http:/ / creativecommons.org/licenses/by/4.0/). 